\title{
Effects of Organizational Entrepreneurship Strategy in Companies Affiliated to the Organization for Development and Renewal of Mining and Mineral Industries of Iran
}

Abbas Ziaeikia ${ }^{1}$ Ph.D. Student, Department of Entrepreneurship, Islamic Azad University, Qazvin, Iran.

Ali Jahangiri ${ }^{2}$ Assistant Professor, Department of Management, Institute for Management and Planning Studies (Corresponding Author).

Javad Mehrabi ${ }^{3}$ Assistant Professor, Department of Management, Islamic Azad University, Qazvin. Iran.

Ali Davari ${ }^{4}$ Assistant Professor, Department of Business Creation, Faculty of Entrepreneurship, University of Tehran.

\section{Abstract}

The present research, intending to study the effects of organizational entrepreneurship strategy, is applied in terms of purpose and survey type based on its method of data collection. After 36 companies from Iran Mining and Mineral Industries Development and Renovation Organization (IMIDRO) were reviewed, results showed that the elements of an organizational entrepreneurship strategy included entrepreneurial strategic vision, organizational architecture supporting entrepreneurial strategy and entrepreneurial tendency and behavior. Then, a conceptual research model was developed and applied in the same companies. To investigate the relationships among variables of the research, linear regression was used and to analyze the data, PLS software was applied due to the low volume of the sample available. Findings show that entrepreneurial strategic viewpoint, entrepreneurial sponsorship architecture, and entrepreneurial tendency and behavior respectively affect individual outcomes of entrepreneurship strategy, organizational outcomes of entrepreneurship strategy, and individual and organizational outcomes of entrepreneurship strategy. It is also known that in the structure of these companies, strategies are not integrated with the concept of enterprise entrepreneurship, nor is there entrepreneurial culture in them. Therefore, it has been suggested that managers at all levels together with specialists of the companies decisively attempt to institutionalize entrepreneurship and create entrepreneurial culture. Also, it has been suggested that cases of individual outcomes of the entrepreneurial strategy such as materializing employees' tacit talents and potentials be taken into consideration so that they can cope with the risks arising from entrepreneurial activities.

Keywords: Corporate Entrepreneurship Strategy, Entrepreneurial

\footnotetext{
Behavior, Organizational Architecture, Eentrepreneurial Awareness, Environmental Factors.
}

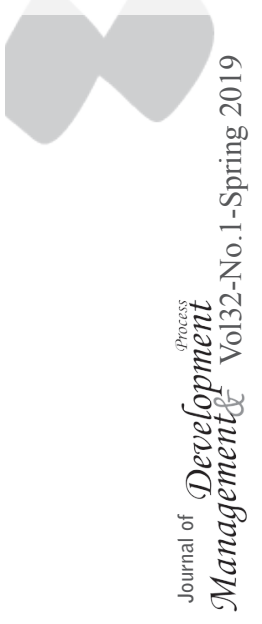

1. a.ziaei@qiau.ac.ir

2. a.jahan@imps.ac.ir

3.mehrabijavad@qiau.ac.ir

4. ali_davari@ut.ac.ir 


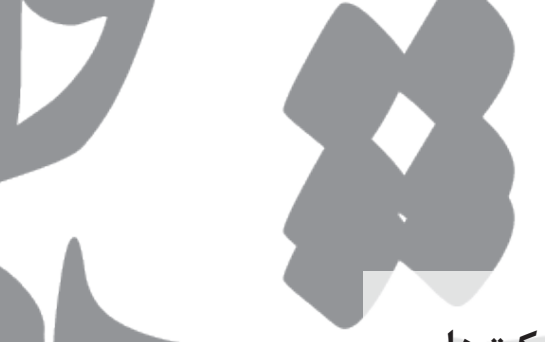

عنوان مقاله: بررسى آثار راهبرد كار آفرينى سازمانى در شركتهاى

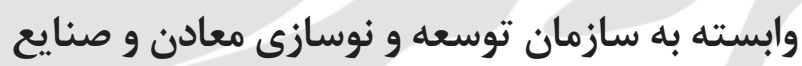

\section{معدنى ايران

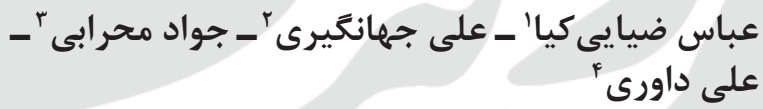

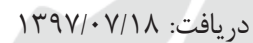

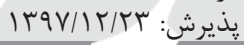

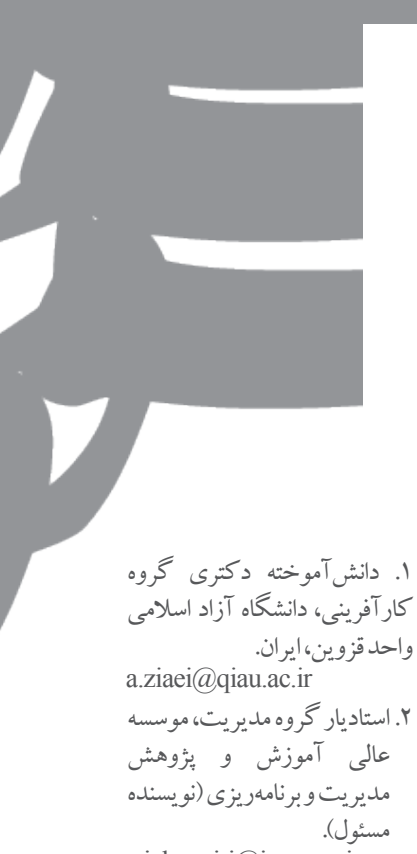

a.jahangiri@imps.ac.ir

r. استاديار گرووهديريت،دانشگاه

آزاد اسلامى واحد قزئروين، ايران.

mehrabijavad@qiau.ac.ir

F. استاديار گحروه كسبو كار،

دانشكده كارآفرينى دانشاء

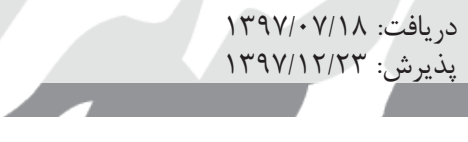

مe

تهران، ايران.

يثوهش حاضر با هدف بررسى آثار راهبرد كارآفرينى سازمانى در شركتهاى وابسته به سازمان توسعه و نوسازى معادن و صنايع معدنى ايران صورت گرفته است. نتايج اين يزوهش كاربردى و ييمايشى، با بررسى وس شركت از اين سازمان نشان مى مدهد كه عناصر تشكيل دهنده راهبرد كارآفرينى سازمانى شامل ديدگًاه راهبردى كارئى آفرينانه، معمارى

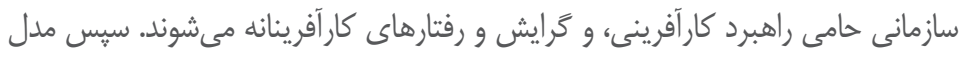
مفهومى يثوهش در شركتهاى تحت يوشش سازمان توسعه و نوسازى معادن و صنايع معدنى ايران (ايميدرو) استفاده شد. در اين راستا، براى بررسى روابط بين متغيرهاى يزئوهش

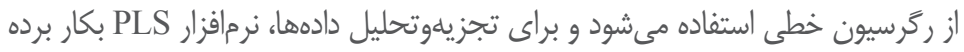

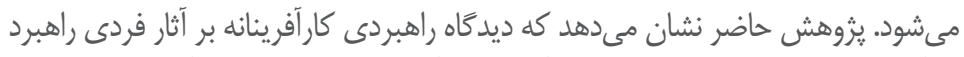

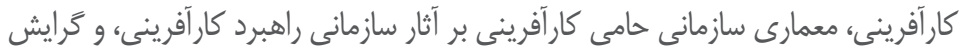

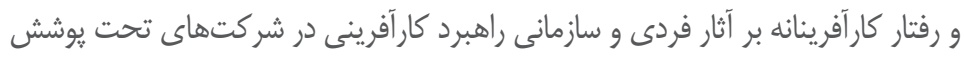

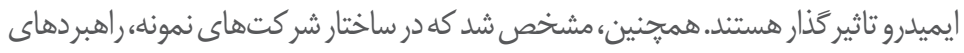

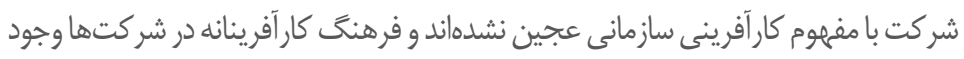

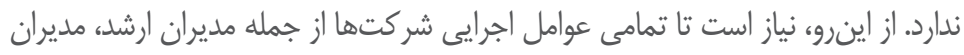

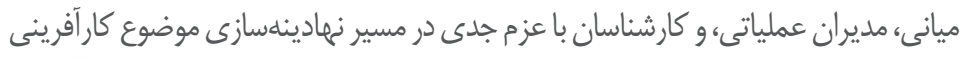

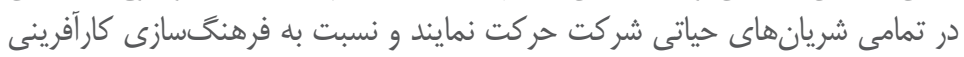

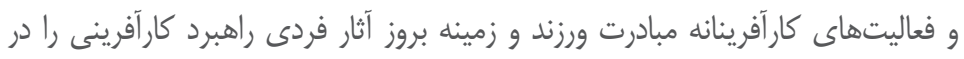

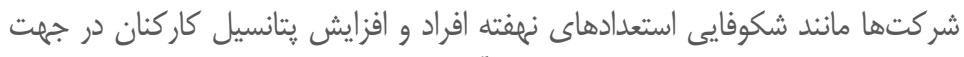

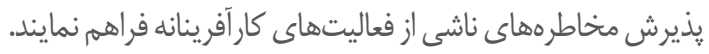

ali_davari@ut.ac.ir

كليدوازهها: راهبرد كار آفرينى سازمانى، رفتار كار آفرينانه، معمارى

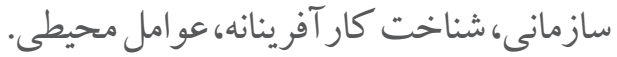




\section{مقدمه}

در طول سه دهه كذشته، شركتها از راهبرد كارآفرينى به عنوان يك ابزار براى ايجاد

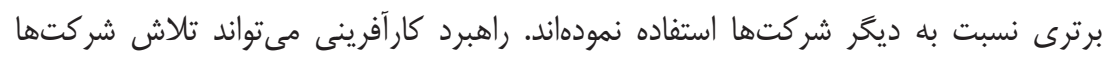

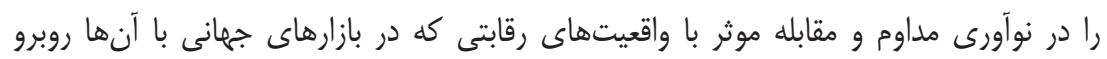

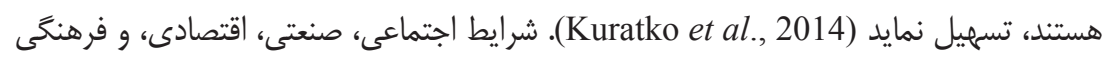

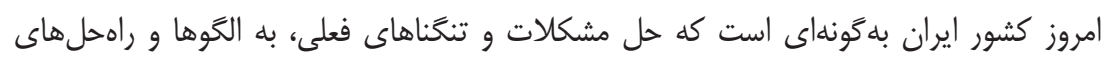

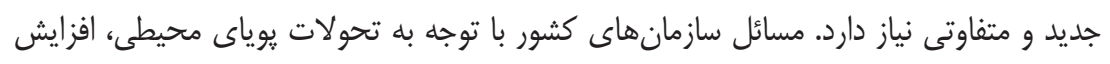

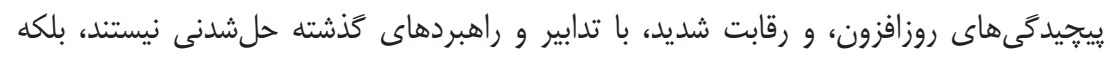

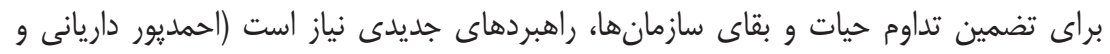

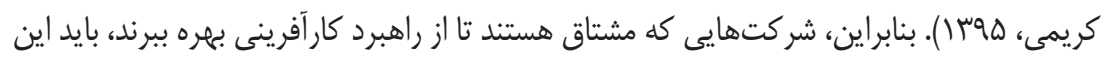

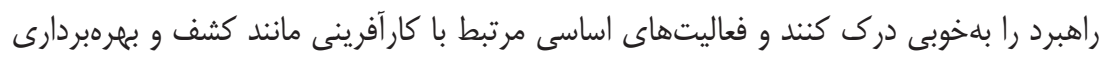

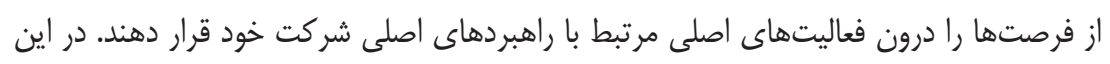

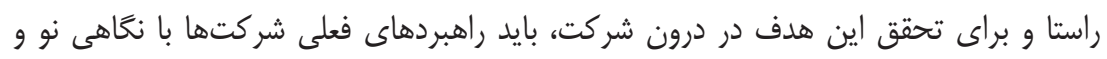

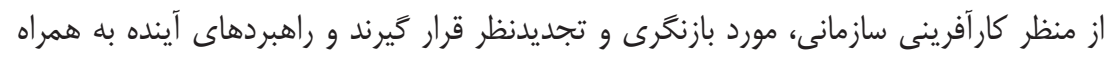

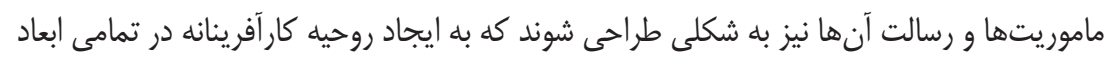

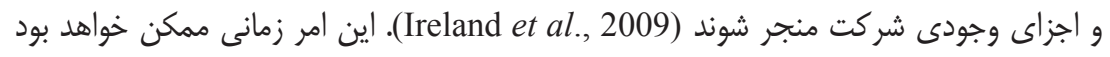
كه مديريت ارشد شركت، با انتخاب مدل مناسب براى كار آفرينى سازمانى، موانع موجود بر سر سر راه

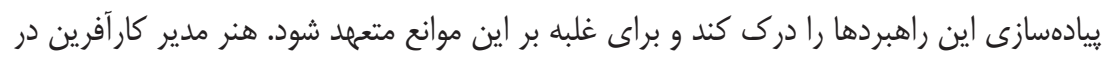

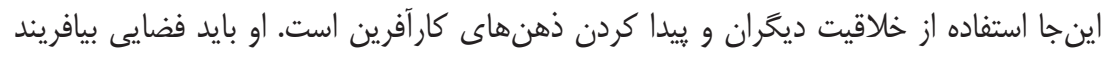

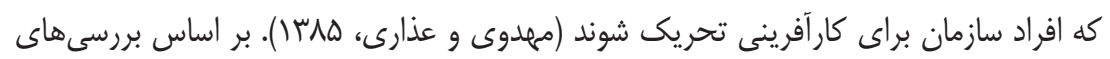

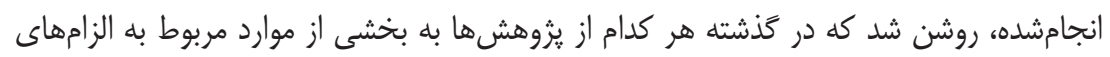

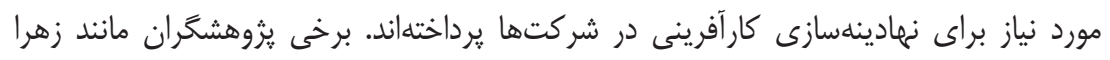

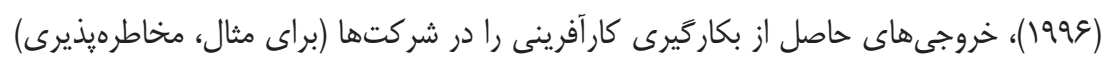

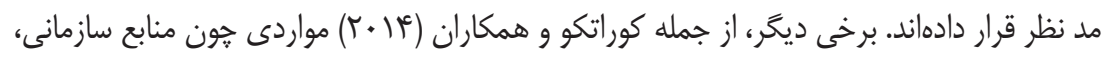

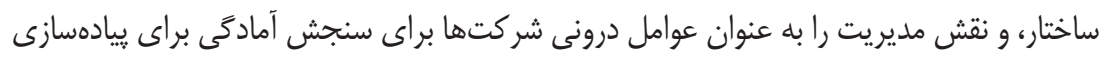


كارآفرينى در سازمان عنوان نمودند. با توجه به اين كه يزوهشكَران در كذشته به صورت موردى

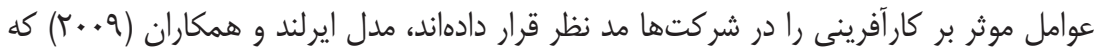

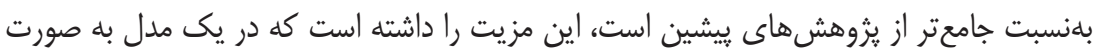

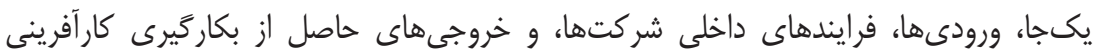

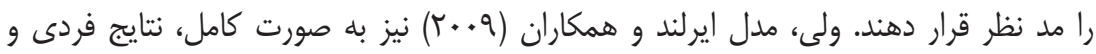

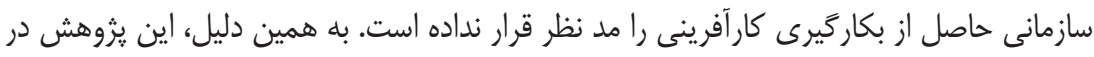

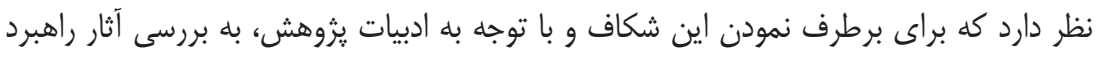

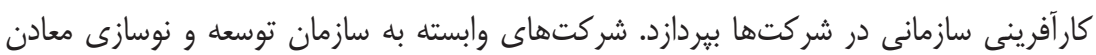

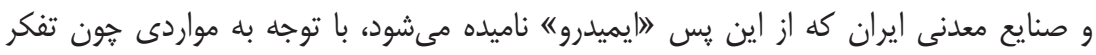

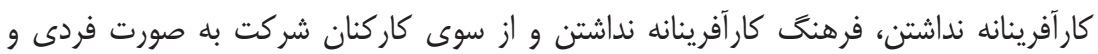

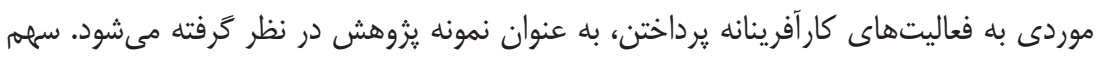

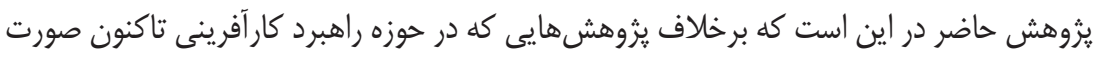

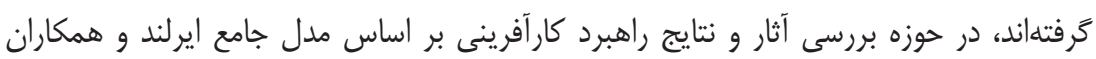

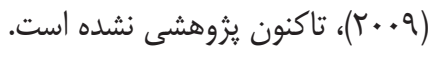

\section{مبانى نظرى و وِيشينهُ وثزوهش}

\section{راهبرد كار آفرينى}

وجود تعاريف متعدد و متنوع از مفهوم كارآفرينى، بر تعاريف راهبرد كارآفرينى نيز تاثيركذار

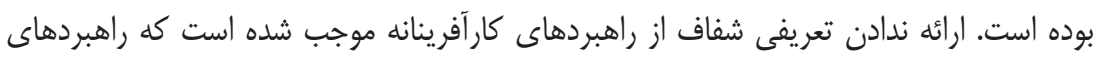

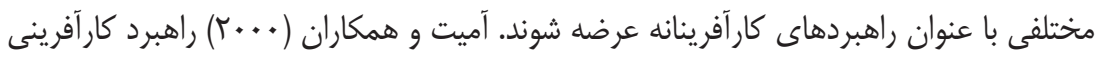

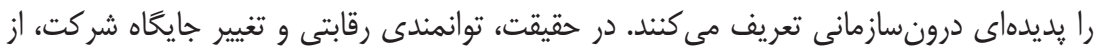

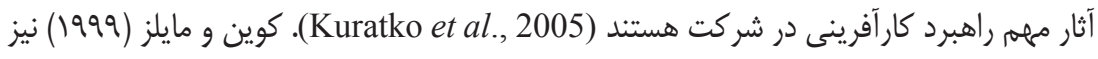

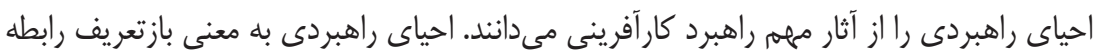

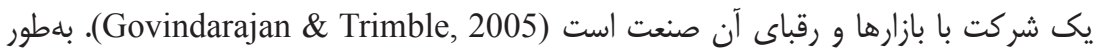

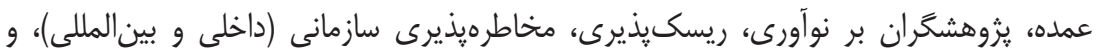

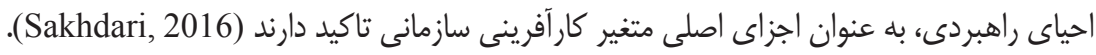

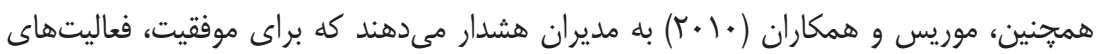


كار آفرينى بايد با راهبردهاى كلى سازمان بهدقت يكيار خه شوند. راهبرد كار آفرينى سازمانى بلطور

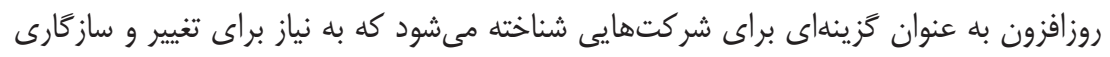

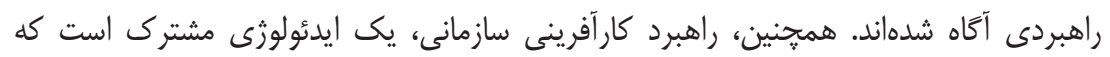

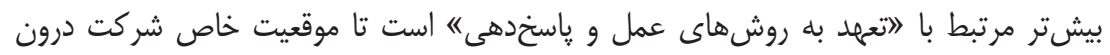

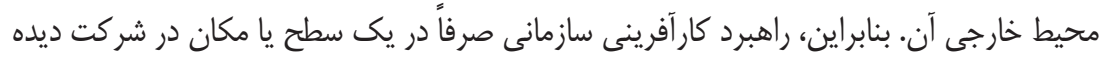

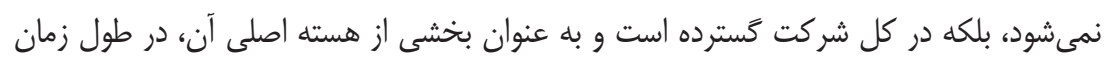

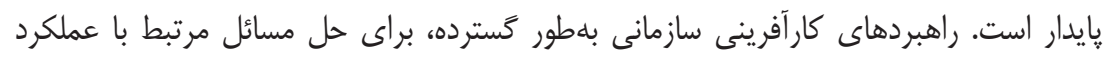

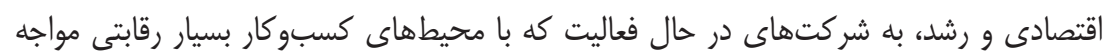

هستند، توصيه مى شوند (Kuratko et al., 2005). به نظر مىرسد كه مرز مشخصى بين راهبرد كارآفرينى سازمانى با مفهوم كارآفرينى راهبردى،

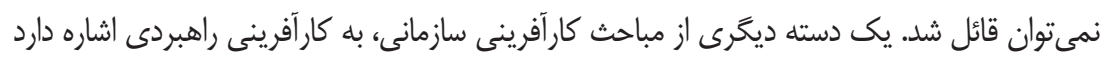
كه شامل تعقيب فرصتهاو رفتارهاى جستجوى مزيت بلهطور همزمان است (Ireland et al., 2003).

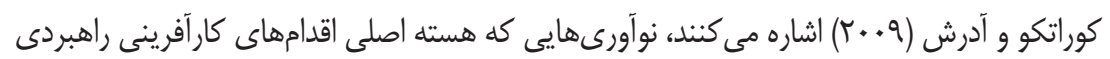

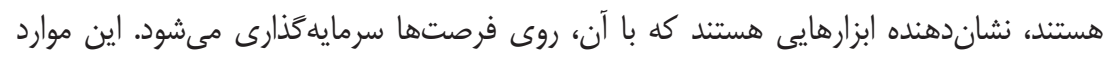

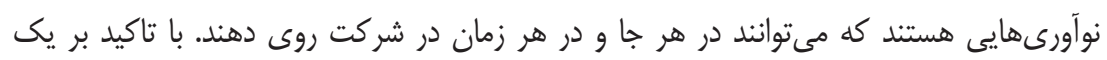

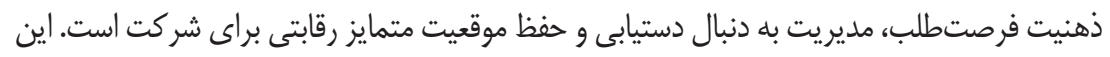

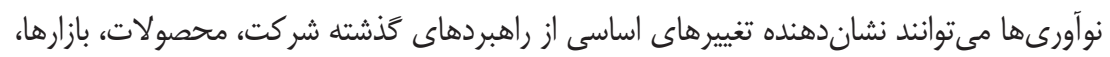

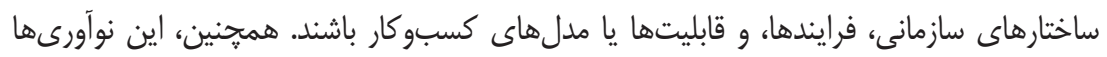

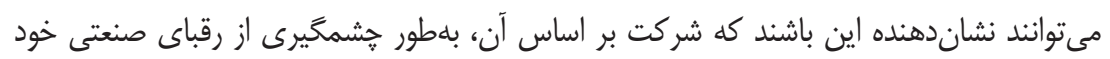

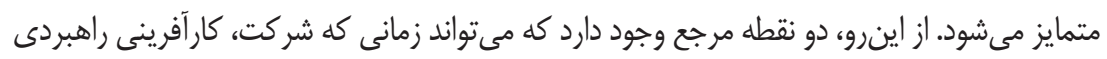

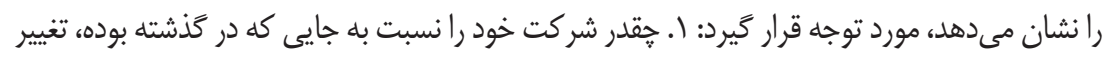

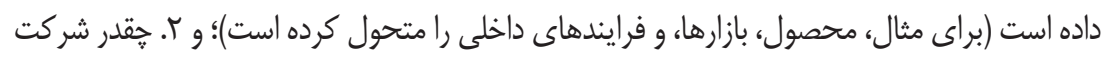

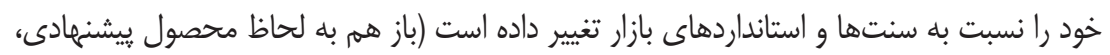

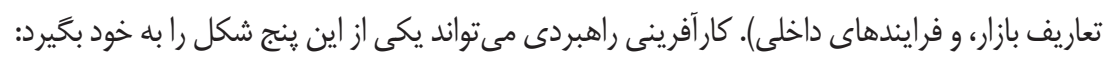

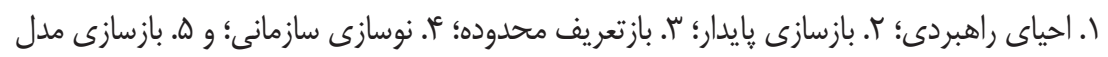
كسبوكار (Ireland \& Webb, 2007; Covin \& Miles, 1999). اكر بخواهيم تعريف كاملى از كار آفرينى راهبردى داشته باشيه، كار آفرينى راهبردى، بار إفتارهاى

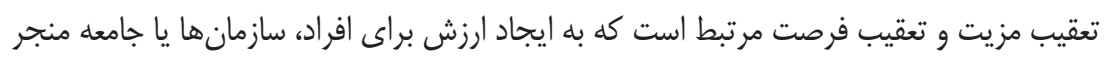


مىشود. اين بدان معناست كه كارآفرينى راهبردى، شامل اقدامهايى است كه براى بهرهبردارى

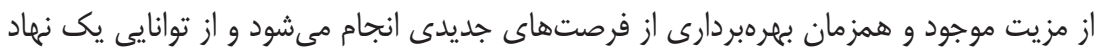

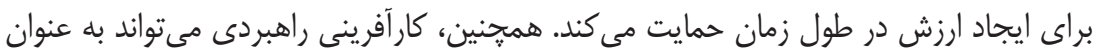

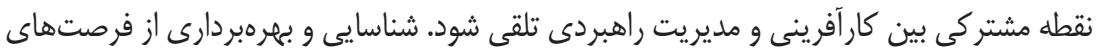

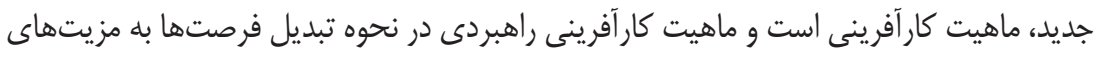

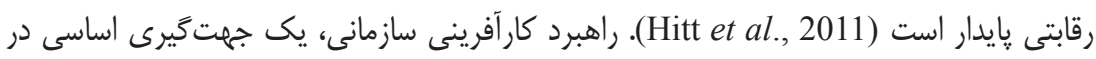

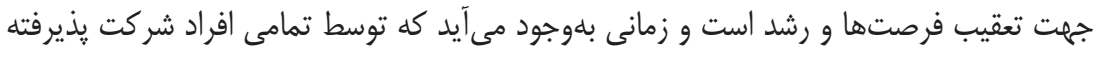
شده باشد و ماهيت كاركرد شركت بر اساس آن تعريف گر دمد (Ireland et al., 2003). اسدى سىسخت و همكاران (باوس|)، تعداد هشت راهبرد كارآفرينانه را مطرح نمودند كه

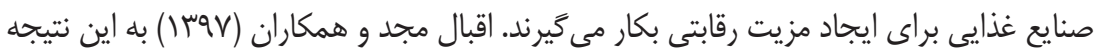

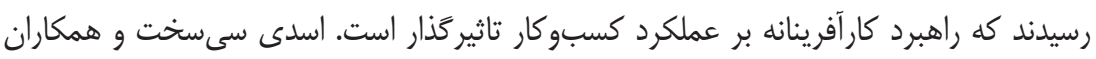

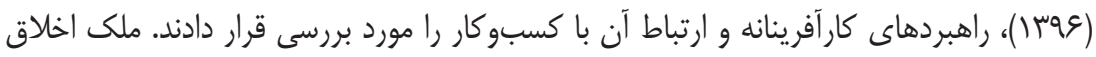

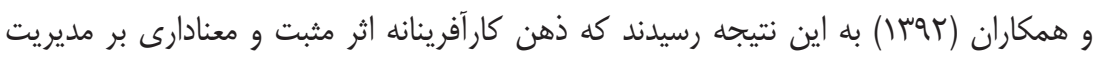

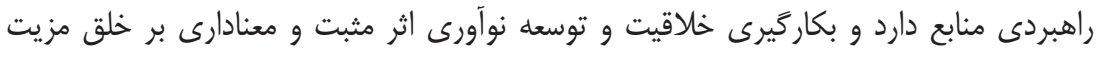

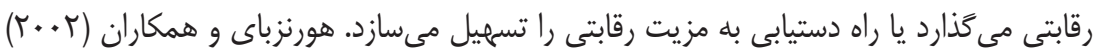

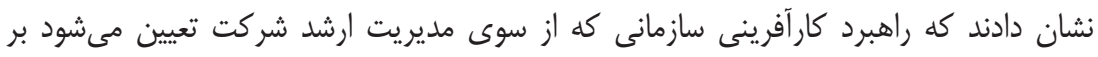

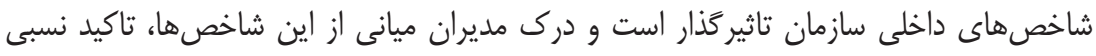

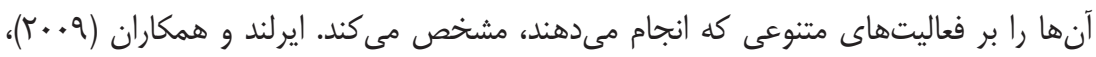

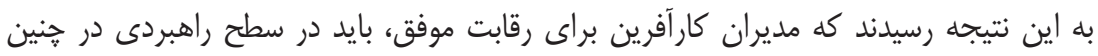

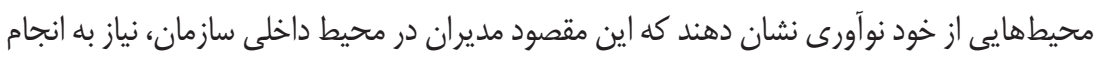

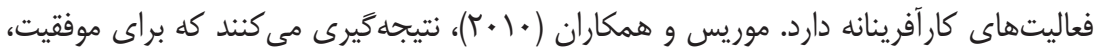

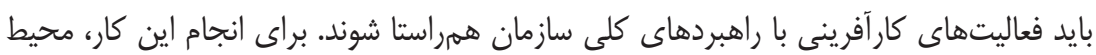

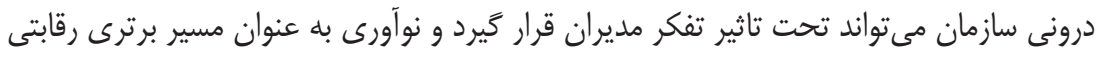

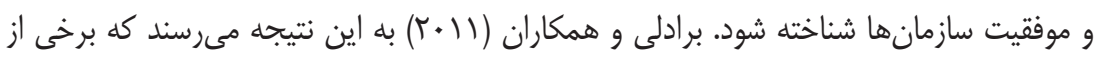
عوامل كنترلنايذير در محيط خارجى به فعاليتهاى كارآفرينى سازمانى مرتبط هستند. كوراتكو و

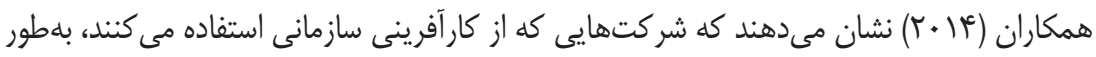

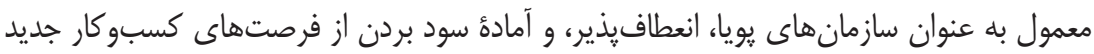
شناخته مىشوند و اين شركتها به دنبال روشهاى جديد انجام كسبوكار هستند. كرافورد و 
كريزر (ها •r) عناصر و گزارههاى مدل راهبرد كار آفرينى سازمانى را كه از سوى ايرلند و همكاران

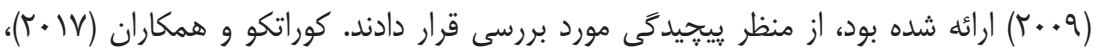

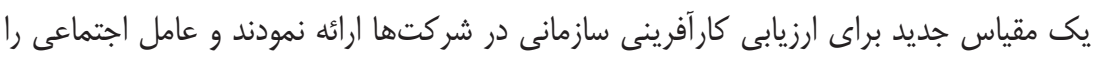

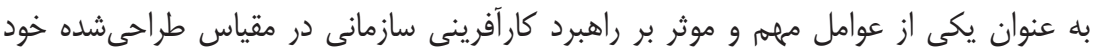

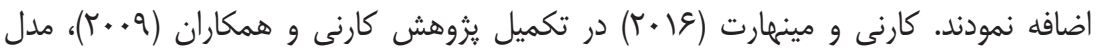

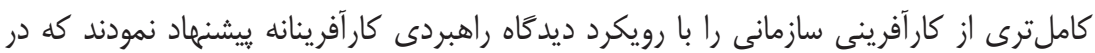

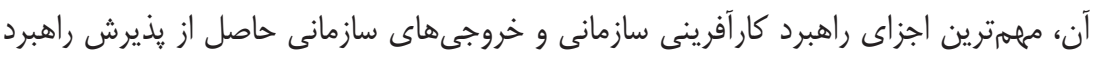

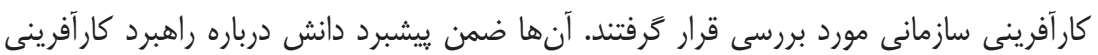

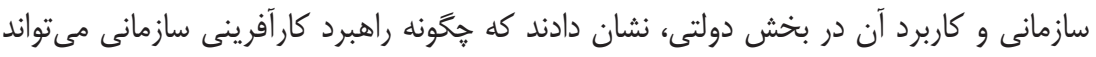

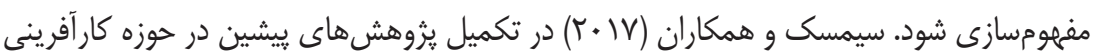
راهبردى، جار خوب مهم و جامعى براى كار آفرينى راهبردى معرفى نمودند و عنوان كردند كه تفكر

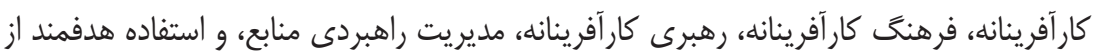

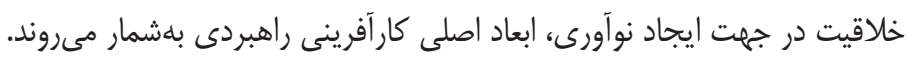

\section{مدل راهبرد كار آفرينى سازمانى ايرلند و همكاران (9+ + ؟)}

مدل ايرلند و همكاران (9.+r) موضوع راهبرد كارآفرينى سازمانى را با نغاهى متفاوت از مدلهاى ييشين مفهومسازى نموده است. با توجه به نغاهى كه اين مدل به صورت جامع به راهبرد

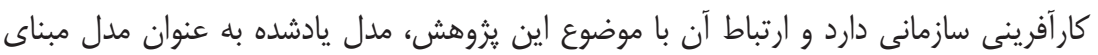

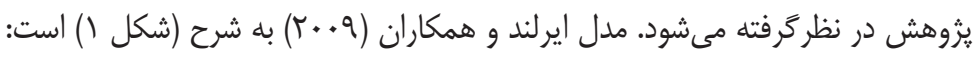

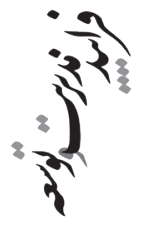




\begin{tabular}{|c|c|c|}
\hline يِيشنيازهاى راهبرد كارآفرينى سازمانى & عناصر راهبرد كارآفرينى سازمانى & نتايج استفاده از راهبرد كارآفرينى سازمانى \\
\hline
\end{tabular}

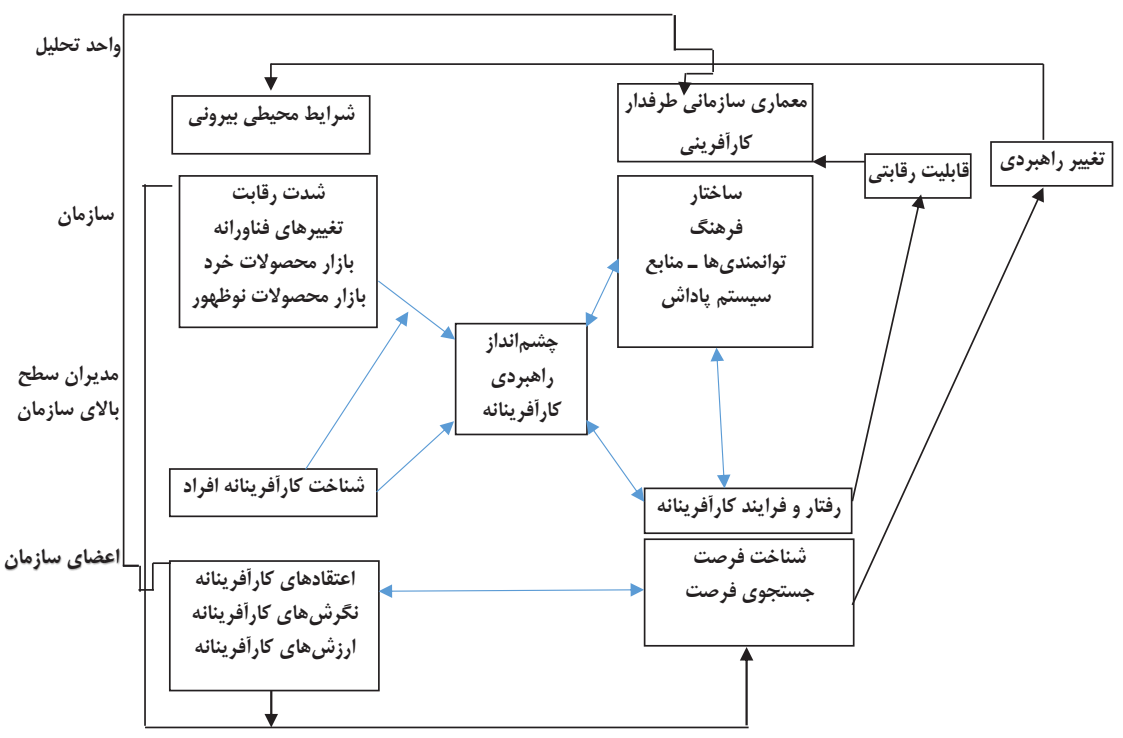

شكل 1: مدل راهبرد كار آفرينى سازمانى (Ireland et al., 2009: 24)

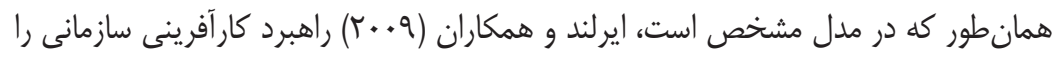

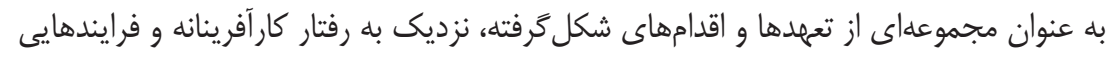

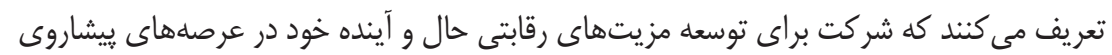

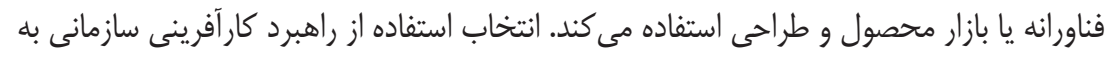

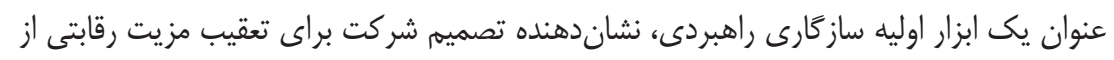
مسير رفتارهاى كارآفرينانه است.

\section{عناصر تشكيلدهنده راهبرد كار آفرينى سازمانى}

ديدكاه راهبردى كارآفرينانه، تصويرى است كه مديران سطح بالا براى سازمان به اميد هدايت

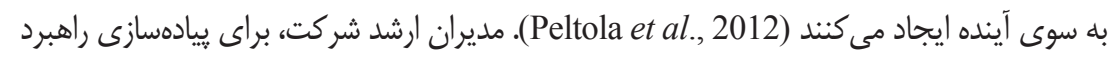

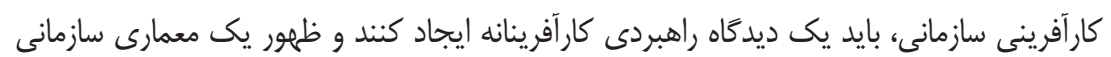

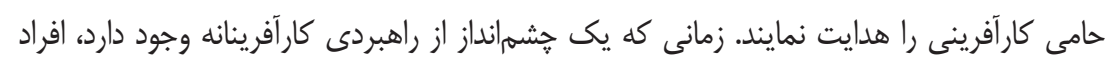
نمى خواهند هيج فرصتى را در محيط از دست دهند (Ireland et al., 2003). 


\section{معمارى سازمانى حامى كار آفرينى}

يك معمارى سازمانى حامى كار آفرينى، محيط سازمانى است كه ويثگى هاى خاصى از لحاظ

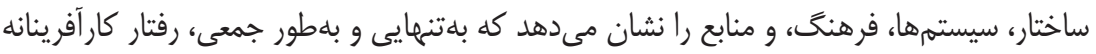

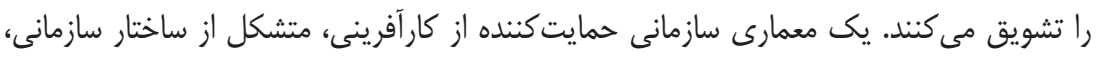

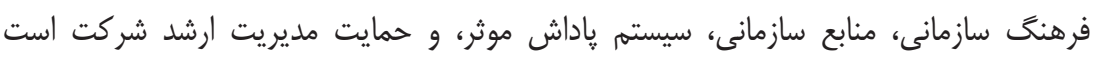
.(Morris \& Kuratko, 2003)

\section{كر ايش و رفتار كار آفرينانه}

رفتار كارآفرينانه، مجموعه جديدى از اقدامهايى است كه شركتها با آن به دنبال بهرهبردارى از

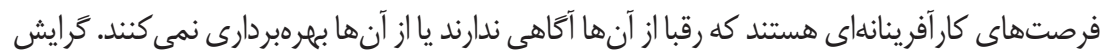

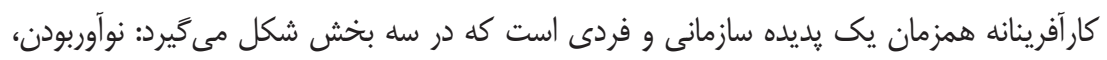

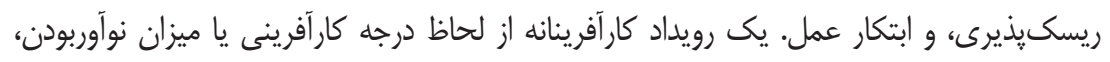

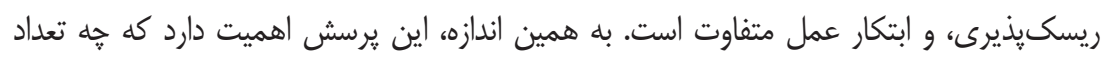

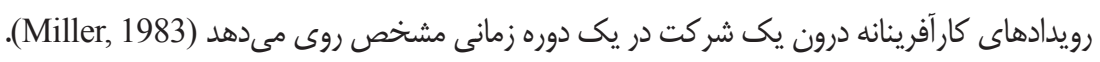

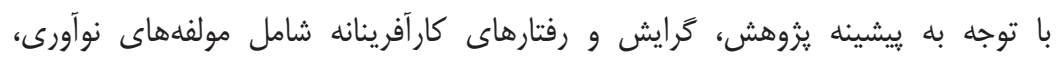

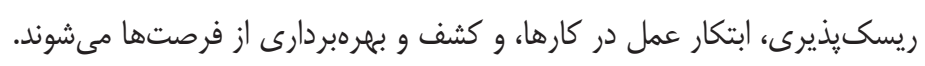

آثار راهبرد كار آفرينى سازمانى خروجى ها و نتايج سازمانى

خروجىهاى سازمانى راهبرد كارآفرينى سازمانى، شامل جيزهايى هستند كه به شركت تعلق

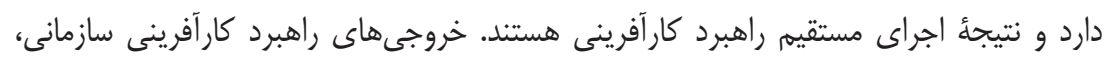

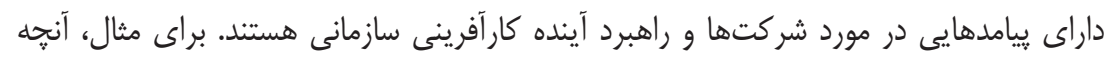

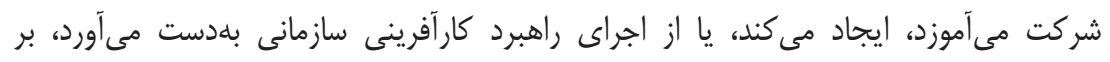

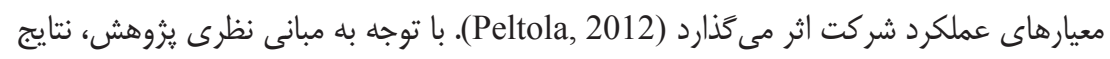

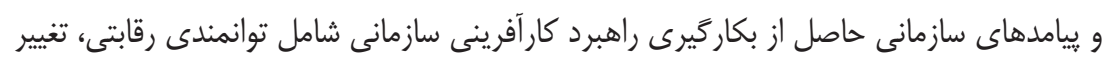
جايخاه راهبردى، و ايجاد ارزش براى مشتريان است. 


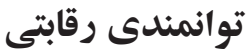

براى دستيابى به توانمندى رقابتى، شركتها بايد راهبردهاى كار آفرينى سازمانى خود را احيا

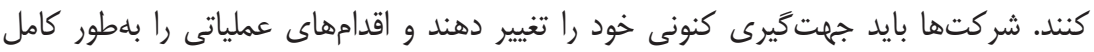

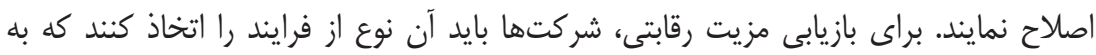
ارزشها مىافزايد (Barney, 1991).

تغيير جايخاه راهبردى، شامل طيف گستردهاى از امكانات شامل استمرار تغييرهاى جزئى، تحول هاى ناييوسته، و طيفى از شرايط شتابدهنده مانند تغييرهاى فناورانه هستند كه مىتوانند

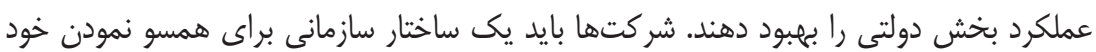

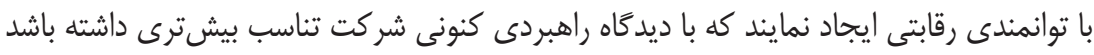
.(Covin \& Miles, 1999)

\section{ايجاد ارزش براى مشتريان}

با بكاركيرى راهبرد كارآفرينى سازمانى، شركت متناسب با توانمندى رقابتى جديد، شروع

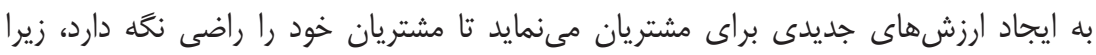

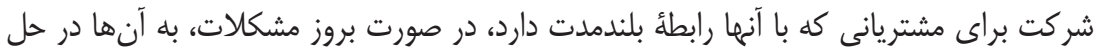

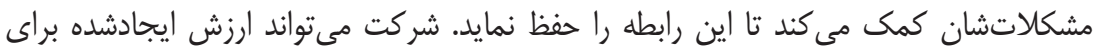

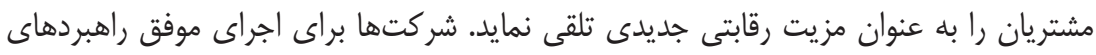
كار آفرينى سازمانى، نياز به مشتريان و شر كاى خارجى دارئ داند (Peltola, 2012).

\section{آثار راهبرد كار آفرينى در افراد}

بر اساس مبانى نظرى يزوهش، نتايج و ييامدهاى فردى حاصل از بكار كيرى راهبرد كار آفرينى

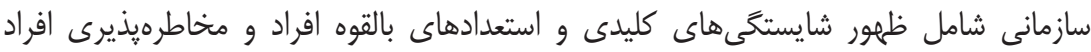




\section{ظهور شايستىىهاى كليدى و استعدادهاى بالقوه افراد}

با بكاركيرى راهبرد كار آفرينى سازمانى، استعدادها، شايستخىها و توانمندى هاى ينهان افراد كه به دليل مهيا نبودن شرايط، امكان ظهور و بروز نداشتهاند، شكوفا مىشود. افراد در يرتوى

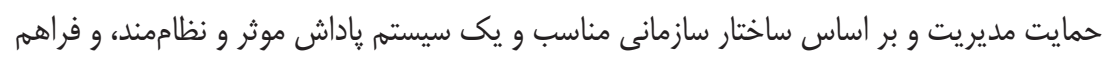

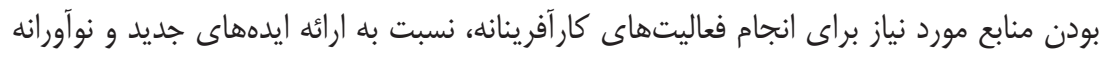

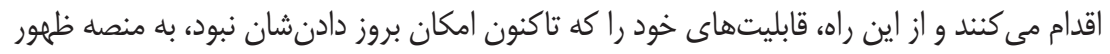

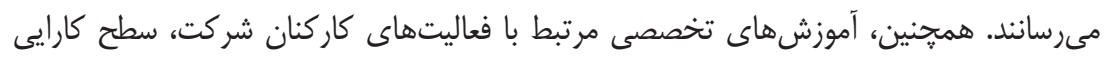
آنها را در شركتها افزايش مىدهد (Guth \& Ginsberg, 1990; Kuratko et al., 2014).

\section{مخاطرهيذيرى افراد}

با بكاركيرى راهبرد كار آفرينى سازمانى، يكى ديخر از مواردى كه تحت حمايت مديريت ارشد

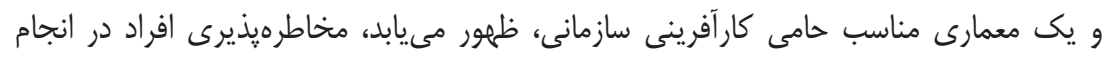

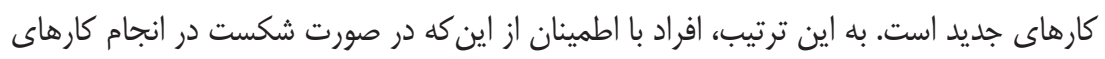

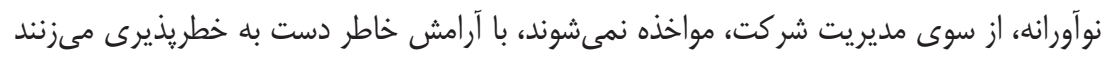

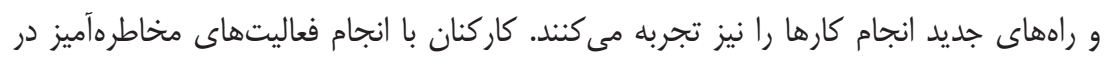

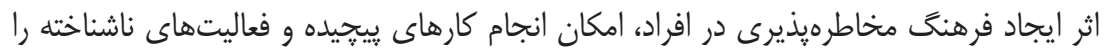

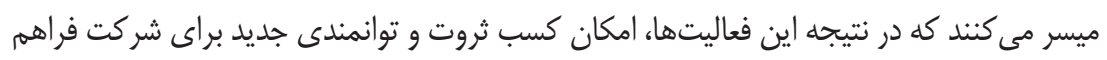
مى گردد (Kearney \& Meynhardt, 2016).

\section{تبيين مل يُ يشنهادى يزوهش}

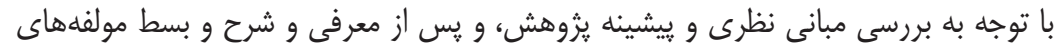

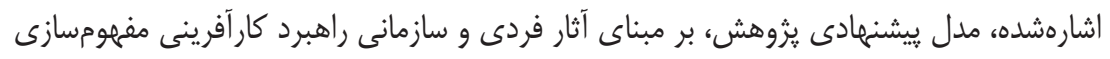

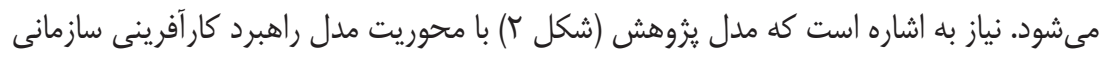

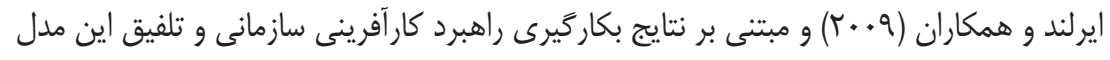

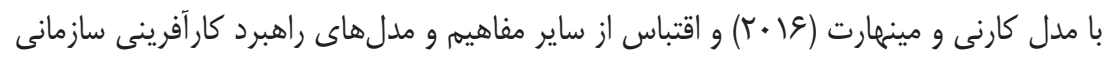
طراحى شده است. 


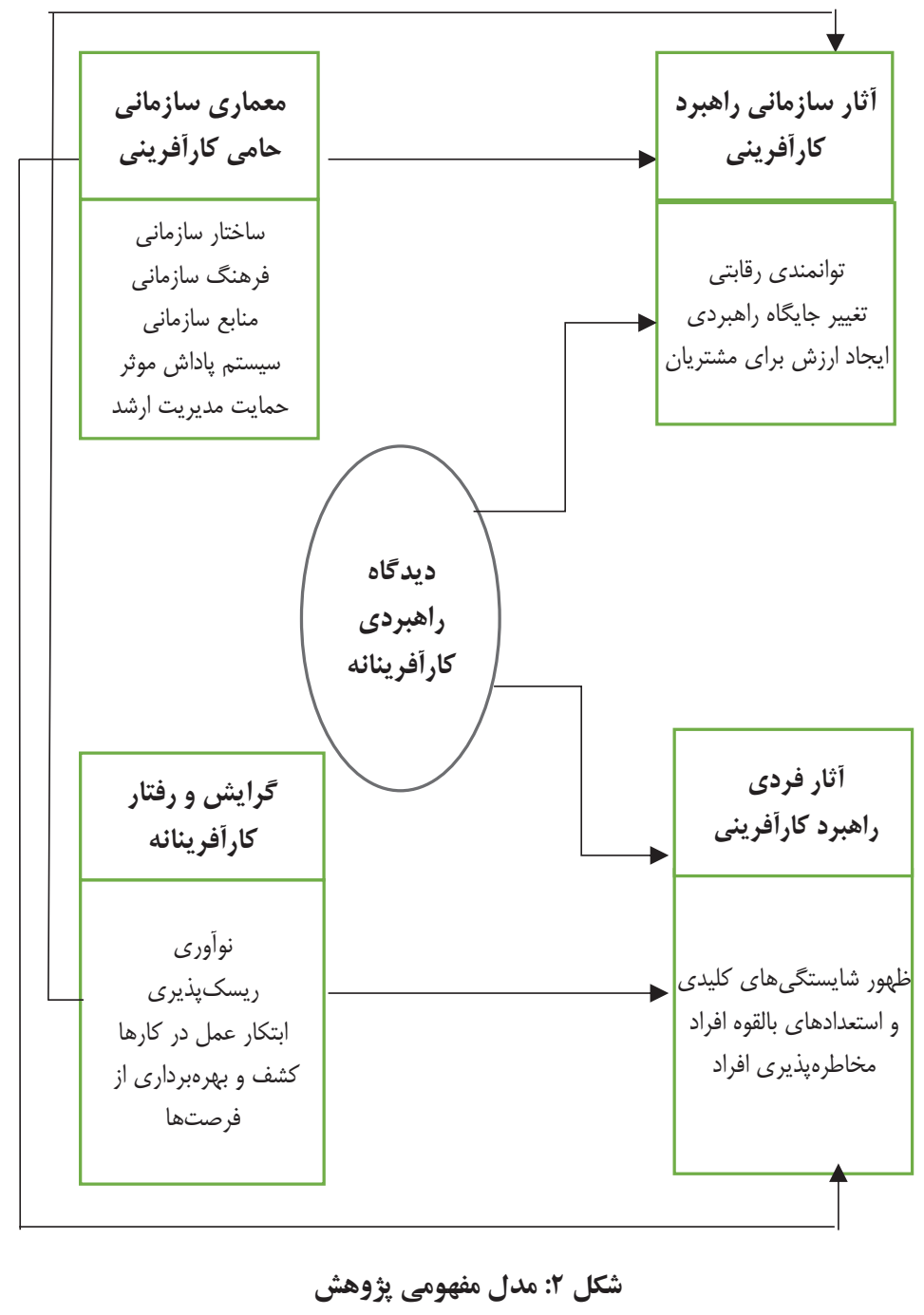

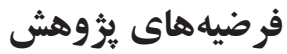

با توجه به مدل ييشنهادى و با توجه به روابط بين مولفهها و متغيرها، و بر اساس مبانى نظرى

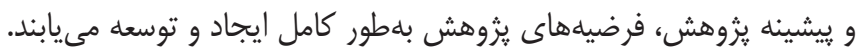

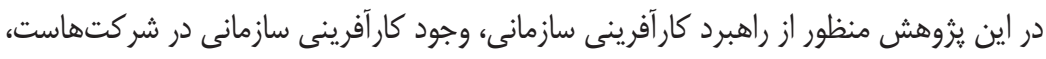

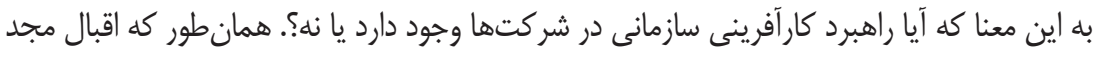


و همكاران (Vوسו) مطرح مى كنند، راهبرد كارآفرينانه بر عملكرد كسبوكار تاثير گذار است. اسدى سىىخت و همكاران (وهسا) نيز ارتباط راهبردهاى كارآفرينانه را با نتايج كسبو كار مورد تاييد قرار دادند. از اينرو، بر اساس مبانى نظرى يثرهش مشخص گرديد كه ديدكاه راهبردى كار آفرينانه مديران ارشد بر نتايج سازمانى حاصل از بكارگيرى راهبرد كارآفرينى سازمانى شامل متغيرهاى توانمندى رقابتى، تغيير جايگاه راهبردى، و ايجاد ارزش براى مشتريان و همجنين، نتايج فردى بكاركيرى راهي راهبرد

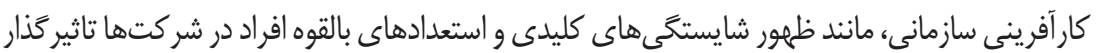
بودهاند. يس، فرضيههاى اول و دوم به شرح ذيل ايجاد و توسعه مىيابند:

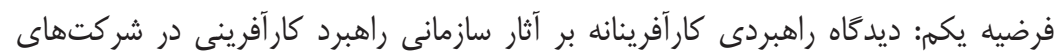
تحت يوشش ايميدرو تاثير گذار است. فرضيه دوم: ديدكاه راهبردى كارآفرينانه بر آثار فردى راهبرد كارآفرينى در شركتهاى تحت يوشش ايميدرو تاثير گذار است. مبتنى بر مبانى نظرى يزوهش، يك معمارى سازمانى حامى كار آفرينى سازمانى متشكل از فرهنگ

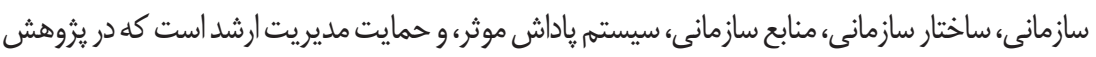

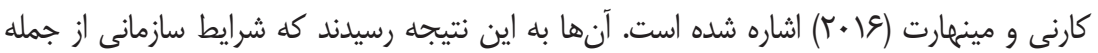
حمايت مديريت ارشد، پاداش، و توانمندسازى بر يِيامدهاى بكارگيرى راهبرد كارآفرينى سازمانى مانند مخاطرهيذيرى سازمانى، نوسازى راهبردى، و ايجاد ارزش عمومى تاثير گذار بوده است. در مدل ايرلند

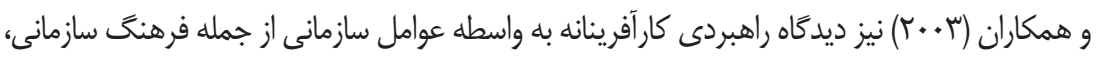
حمايت مديريت ارشد، و رفتارها و فرايندهاى كارآفرينانه بر نتايج مديريتى و سازمانى ناشى از بكارگيرى

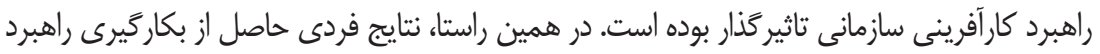

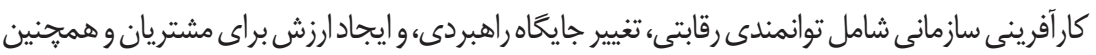
$\int^{2} \frac{2}{3}$ نتايج سازمانى بكارگيرى راهبرد كار آفرينى سازمانى شامل ظهور شايستخى هاى كليدى و استعدادهاى بالقوهير افر اد مى شوند كه به صورت مشروح در بخش مبانى نظرى يثوهش مورد بررسى قرار گرفتند. از اينرو:

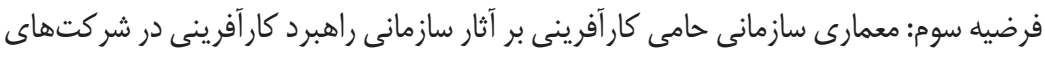
تحت يوشش ايميدرو تاثير گذار است. فرضيه جهارم: معمارى سازمانى حامى كار آفرينى بر آثار فردى راهبرد كارآفرينى در شركتهاى لهاى تحت يوشش ايميدرو تاثير گذار است. از آنجا كه ايرلند و همكاران (9 +. (r)، به اين نتيجه رسيدند كه مديران كارآفرين بايد براى رقابت موفق، در سطح راهبردى در جنين محيطهايى از خود نوآورى نشان دهند، و براى دستيابى 
به اين مقصود نياز است تا مديران در محيط داخلى سازمان، به انجام فعاليتها و رفتارهاى

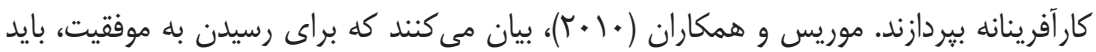

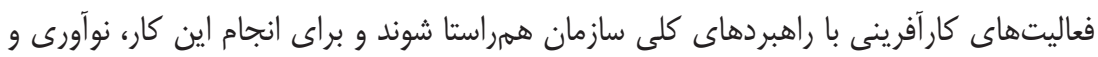

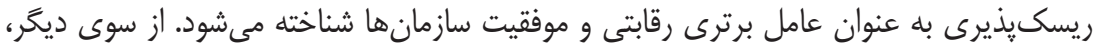

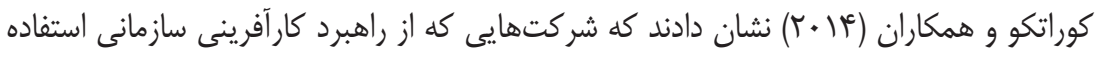

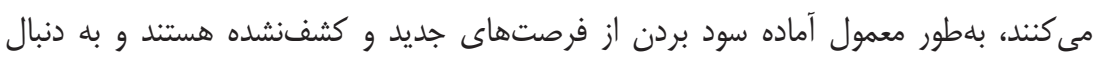
روشهاى نوآورانه براى انجام كسبو كار هستند. در يزوهش ايرلند و همكاران (9. +.؟)، نيز آشكار

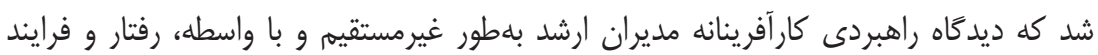

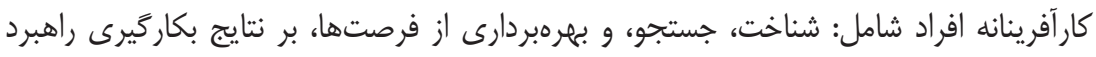

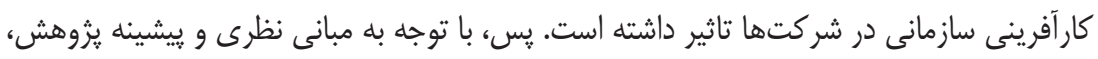

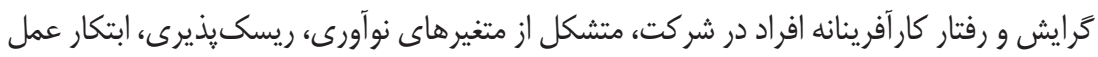

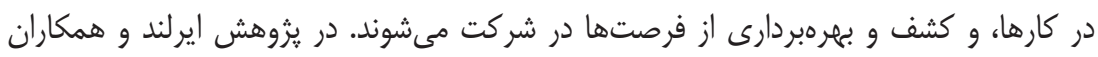

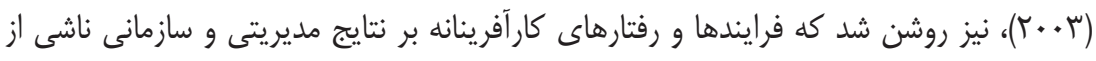

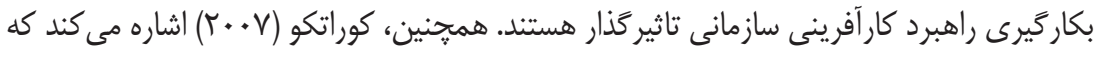

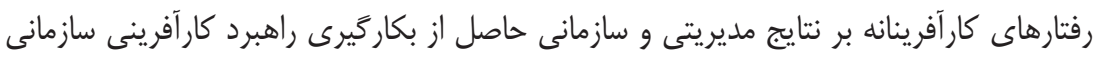

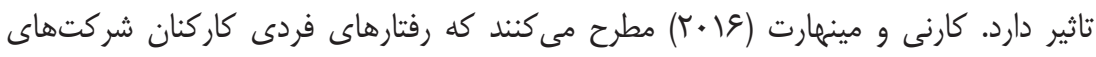

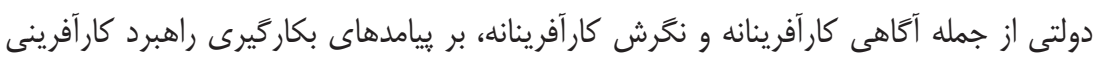

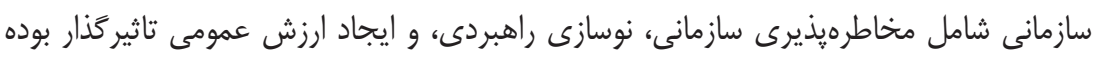

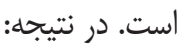

فرضيه ينجم: كرايش و رفتار كار آفرينانه بر آثار سازمانى راهبرد كارآفرينى در شر كتهاى تحت يوشش ايميدرو تاثير كذار است. فرضيه ششم: كرايش و رفتار كارآفرينانه بر آثار فردى راهبرد كارآفرينى در شركتهاى تحت يوشش ايميدرو تاثير كذار است

روش

هدف اصلى اين يزوهش، بررسى آثار راهبرد كار آفرينى سازمانى در شركتهاست. يزوهش حاضر

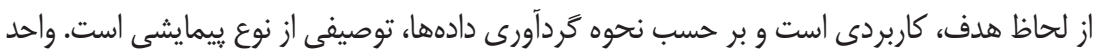

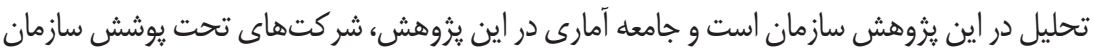


توسعه و نوسازى معادن و صنايع معدنى ايران هستند. براى تجزيهوتحليل دادها از نرمافزار PLS

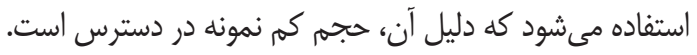

\section{روش سنجش متغير هاى بزوهش}

جدول (1) نحوه سنجش متغيرها را نشان مىدهد. همانطور كه در جدول (ا) يبداست،

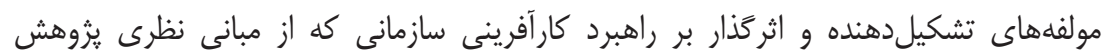
استخراج شدهاند، بيان شده است.

جدول 1: سنجش متغيرهاى يزوهش

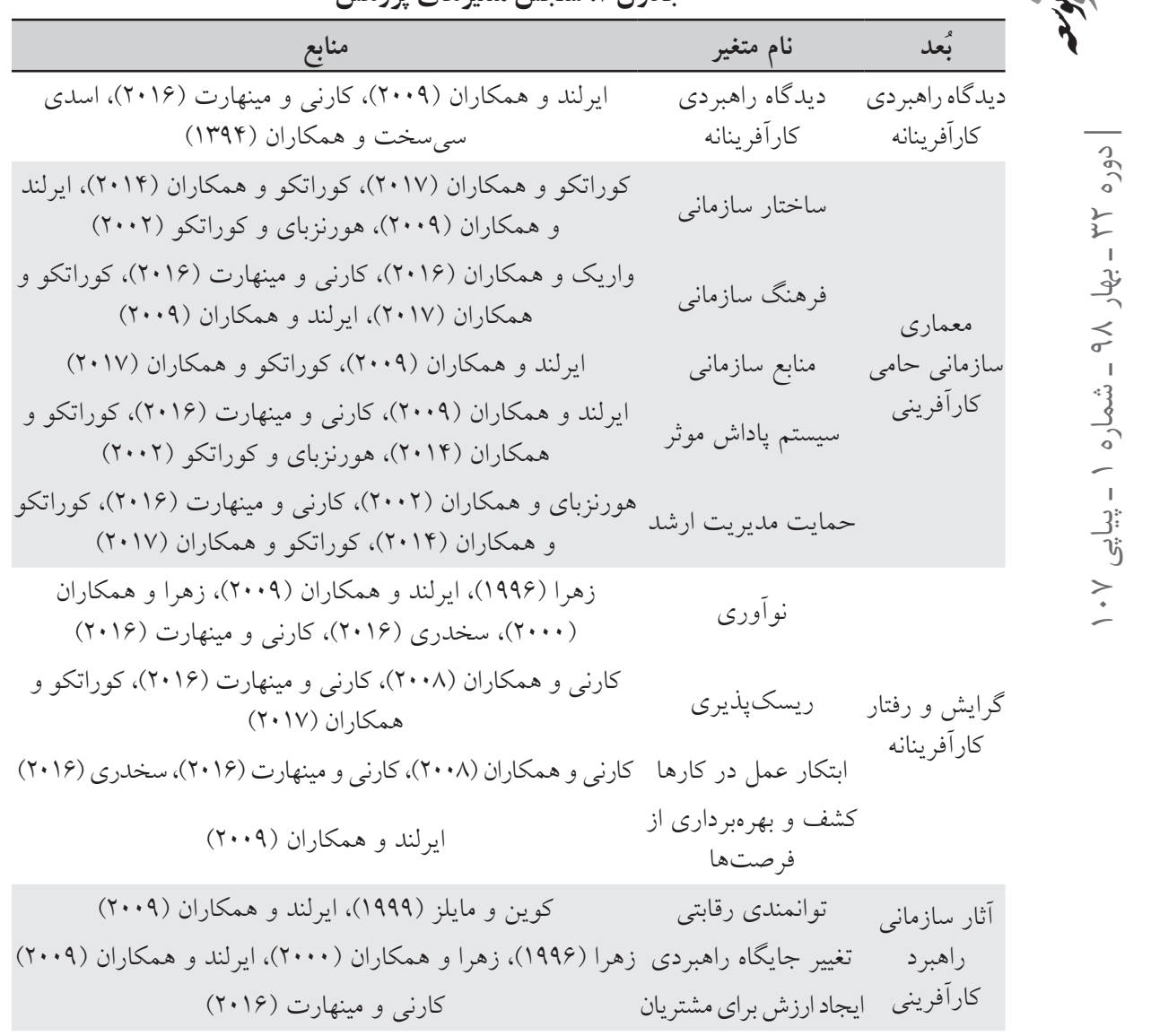




\begin{tabular}{|c|c|c|}
\hline منابع & نام متغير & بُعد \\
\hline 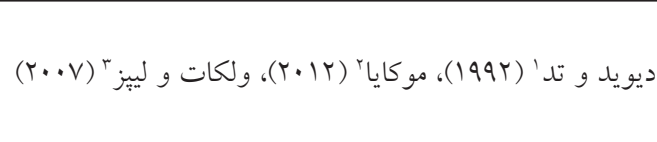 & ظليدى شور شايستخى استعدادهاى & 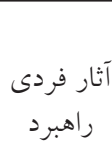 \\
\hline 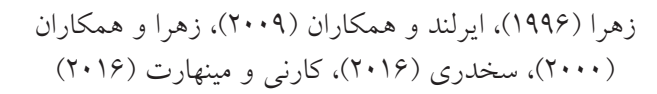 & مخاطرهيذيرى افراد & كار آفرينى \\
\hline
\end{tabular}

براى تهيه و تنظيم يرسشنامه، يس از استخراج متغيرهاى يثوهش، طراحى يرسشنامه بر اساس

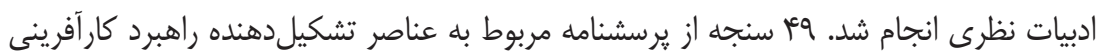

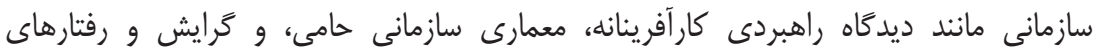

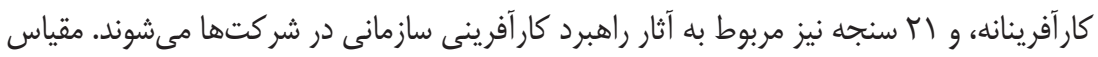
اندازهگيرى در اين يزوهش، طيف ليكرت ينجزَينهاى است. براى تعيين روايى صورى يرسشنامه،

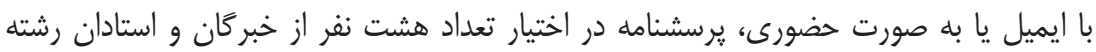

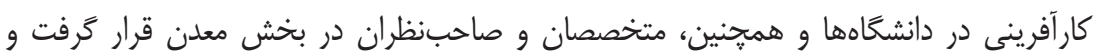
روايى صورى و محتوايى آن، از سوى خبركان تاييد گرديد. سيس، براى تعيين پايايى يرسشنامه از

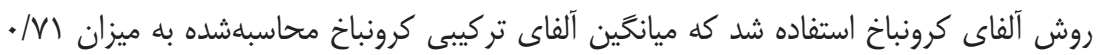
بلهدست آمد. اين عدد نشان مىدهد كه يرسشنامه از رايايى بلهنسبت خوبى برخوردار است. با وجود

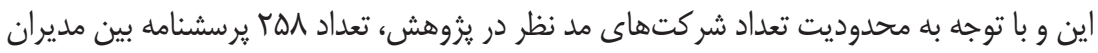
و كارشناسان، و بر اساس اندازه هر شركت، طبق جدول (r) توزيع گرديدند:

1. David \& Ted

2. Mokaya

3. Wolcott \& Lippitz 


\section{جدول r: نحوه توزيع برسشنامهها در شركتها}

\begin{tabular}{|c|c|c|c|c|c|c|}
\hline جمع & مديران & كارشناسان & شر كت & 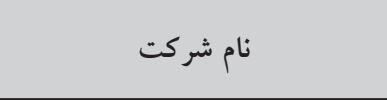 & رديف & ن ام گروه \\
\hline 4 & $r$ & $r$ & متوسط & شركت ملى فولاد ايران & 1 & \multirow{7}{*}{ 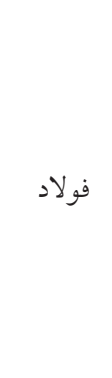 } \\
\hline $1 \cdot$ & $\omega$ & 0 & 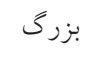 & شركت فولاد مباركه اصفهان & r & \\
\hline $1 \cdot$ & $\Delta$ & 0 & 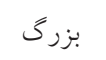 & شركت فولاد آذربايجان & r & \\
\hline $1 \cdot$ & 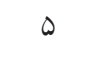 & 0 & 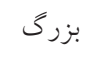 & شركت فولاد هرمز گان & r & \\
\hline $1 \cdot$ & $\omega$ & 0 & 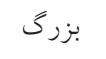 & شركت فولاد خراسان & 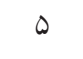 & \\
\hline $1 \cdot$ & $\Delta$ & 0 & 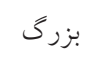 & شركت فولاد خوزستان & 4 & \\
\hline $1 \cdot$ & $\Delta$ & 0 & 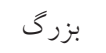 & شركت ذوبآهن اصفهان & $\checkmark$ & \\
\hline 1. & $\Delta$ & 0 & 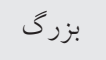 & شركت تهيه و توليد مو اد معلنى ايران & $\wedge$ & \multirow{7}{*}{ 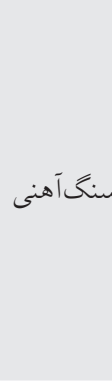 } \\
\hline $1 \cdot$ & $\Delta$ & 0 & 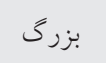 & شركت سنگ آهن فلات مركزى ايران & 9 & \\
\hline 1. & $\omega$ & 0 & 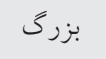 & شركت سنخ آهن مركزى بافق & 1. & \\
\hline 9 & r & r & متوسط & شركت سنگ آهن سير جان & 11 & \\
\hline 4 & r & r & 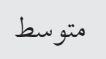 & شركت سنگ آهن جلال آباد & ir & \\
\hline 1. & $\Delta$ & $\Delta$ & 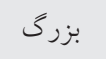 & شركت سنگ آهن كَل گهر & ir & \\
\hline 1. & 0 & $\Delta$ & 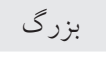 & شركت سنخ آهن جادرملو & 14 & \\
\hline 9 & r & r & متوسط & مجتمع معدنى طلاى زرشوران & 10 & \multirow{8}{*}{ 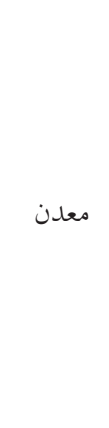 } \\
\hline 9 & r & r & 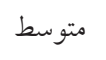 & شركت سرب و روى مهدى آباد & 19 & \\
\hline 4 & r & r & 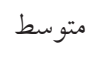 & شركت سرب و روى انكوران & IV & \\
\hline r & r & r & كوجى & مجتمع سنگ آهك بيربكران & 11 & \\
\hline 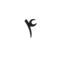 & r & r & كوجنى & مجتمع پتاس خور و بيابانك & 19 & \\
\hline$r$ & r & r & كو:צى & مجتمع معدنى طلاى موته & $r \cdot$ & \\
\hline 4 & r & r & 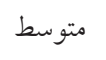 & شركت ذغالسنگ البرز مركزى & r) & \\
\hline 4 & r & r & متوسط & شركت ذغالسنگ يروده طبس & rt & \\
\hline
\end{tabular}
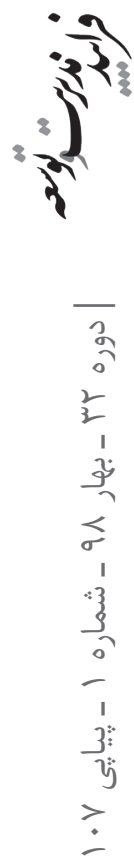
ادامه جدول r: نحوه توزيع برسشنامهها در شركتها

\begin{tabular}{|c|c|c|c|c|c|c|}
\hline 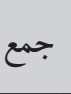 & مديران & كارشناسان & شر كت & 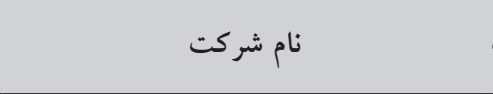 & رديف & 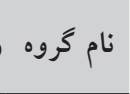 \\
\hline r & r & r & كوجى & طرح زيربناهاى لازم در معادن بزرى & r & \multirow{9}{*}{ 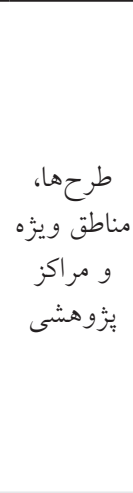 } \\
\hline r & r & r & كوجى & طرح توليد آلومينا از نفلين سينيت سراب & ry & \\
\hline r & r & r & كوجى & طرح ايجاد كارخانه الكترود كرافيتى اردكان & ro & \\
\hline r & r & r & كوجى & منطقه ويزه اقتصادى صنايع انرزى بر لامرد & rq & \\
\hline q & r & r & كوجى & منطقه ويزه اقتصادى صنايع انرزى بر پيارسيان & TV & \\
\hline $1 \cdot$ & $\Delta$ & 0 & 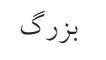 & منطقه ويزه صنايع معلنى و فلزى خليجفارس & rی & \\
\hline 4 & r & r & 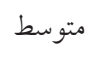 & مركز تحقيقات يِيشرفتـه فراورى مواد معلنى كرج & rq & \\
\hline 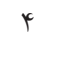 & r & r & كوجنى & مركز تحقيقات فراورى مو اد معلى ايران (يزد) & $\mu$. & \\
\hline 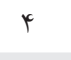 & r & r & كوجنى & طرح تيتانيوم كهنوج & $\mu$ & \\
\hline 1. & 0 & 0 & 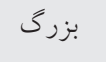 & شركت آلوميناى ايران (جاجرم) & rT & 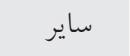 \\
\hline 1. & 0 & 0 & 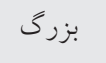 & شركت آلومينيوم المهدى بندرعباس & r & 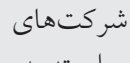 \\
\hline 1. & 0 & $\Delta$ & 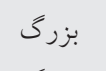 & شركت آلومينيوم اراى & ry & حوز وابسته بله \\
\hline 1. & 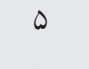 & 0 & 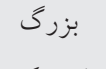 & شركت ملى صنايع مس ايران & ro & و صنايع \\
\hline${ }^{r}$ & $r$ & $r$ & كوجى & صندوق بيمه سرمايه گذارى فعاليتهاى معلنى & re & معنى \\
\hline & & & $r \Delta \wedge$ & $1 r q$ & $1 \% 9$ & جمع كل \\
\hline
\end{tabular}

همانطور كه از جدول (؟) مشخص است، تعداد عب شركت از شركتهاى در دسترس ايميدرو

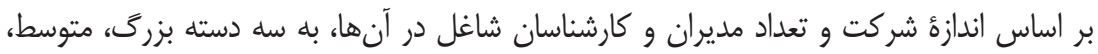

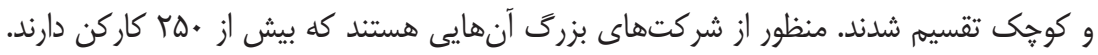
شركتهاى متوسط آنهايى هستند كه داراى تعداد كاركن بين •ه تا • • هستند و شركتهاى

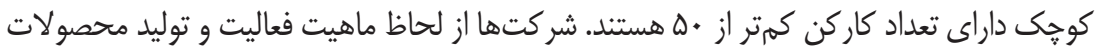

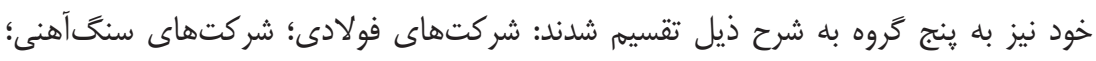
شركتهاى معدنى؛ طرحها، مناطق ويزه و مراكز يزوهشى؛ و ساير شركتهاى وابسته به حوزه معلن و صنايع معدنى. يرسشنامه بر اساس تعداد مشخصى براى هر شركت ارسال، و در توضيحاتى كه در نامهاى

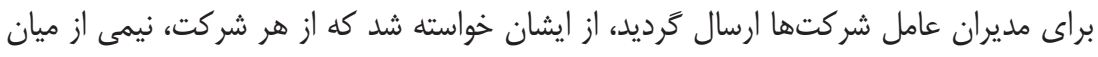

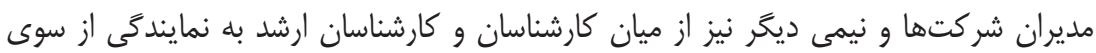


شركت، در نظرسنجى مشاركت نمايند. در خصوص جَكونكى نحوه توزيع و تكميل يرسشنامها،

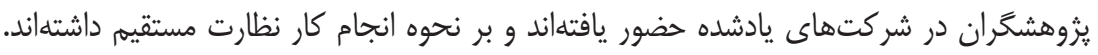

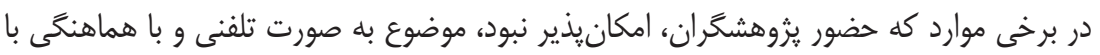

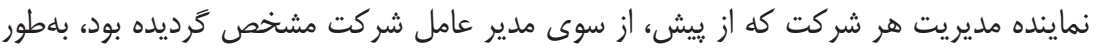

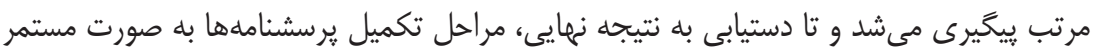

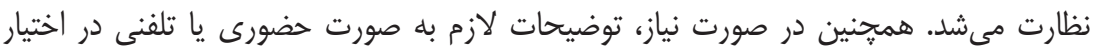

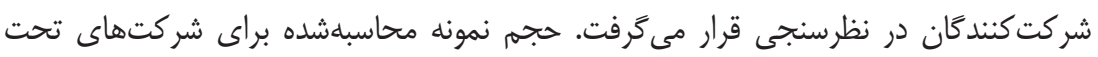

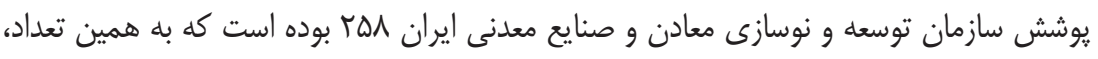

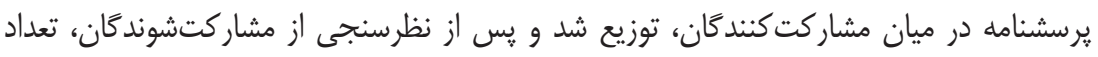

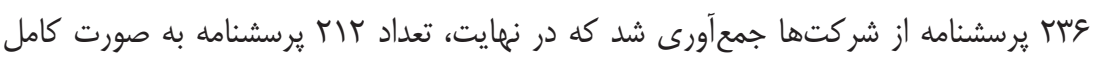

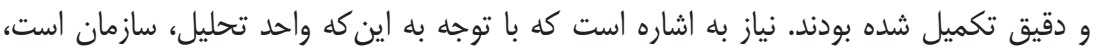

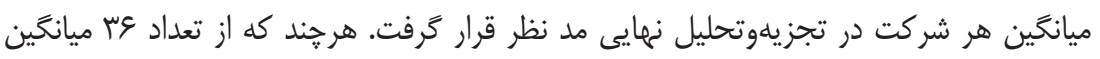

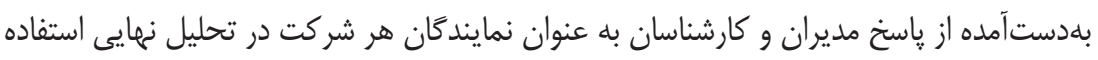

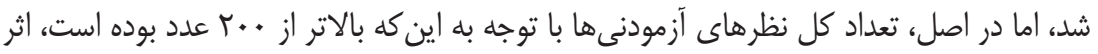
خود را در معنادارى روابط خواهد كذاشت.

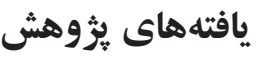

براى تعيين آثار راهبرد كارآفرينى سازمانى در شركتهاى تحت يوشش ايميدرو، بر اساس

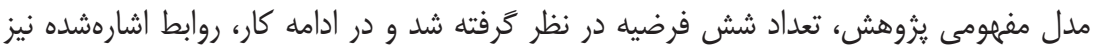
آزمون گر ديدند.

\section{آزمون ركر سيون خطى}

براى بررسى فرضيههاى يزوهش و تاثير متغيرها بر يكديخر از آزمون ركَرسيون خطى جند آنانه

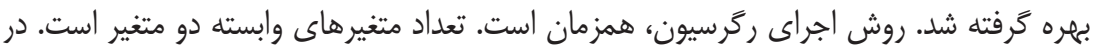

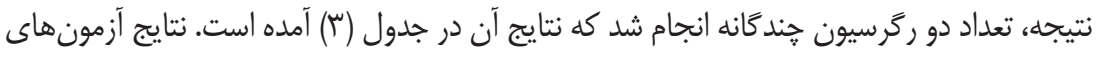

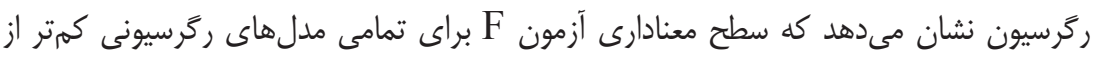

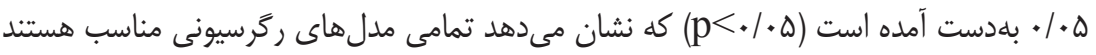

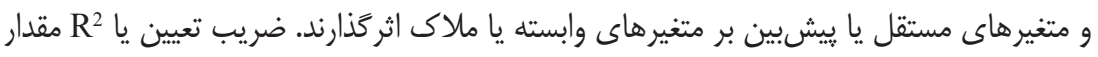


واريانس متغير وابسته را نشان مىدهد كه توسط متغيرهاى مستقل تبيين شده است. بالاترين

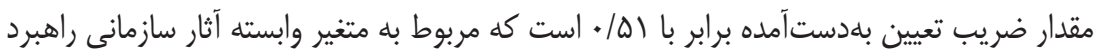

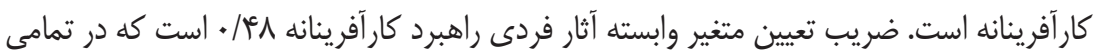
موارد، ضريب تعيين بهدستآمده مقادير قابل قبولى هستند.

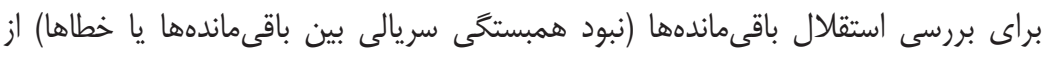

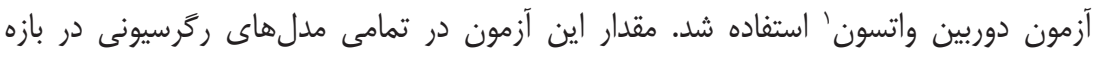

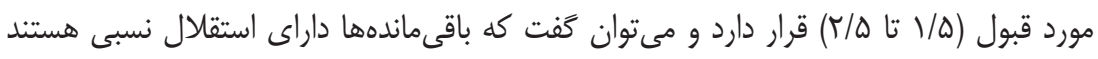

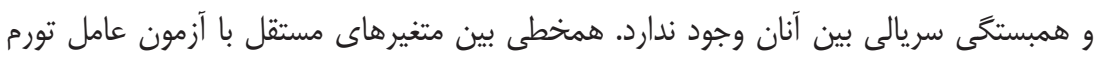

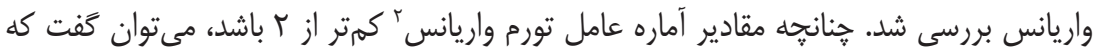

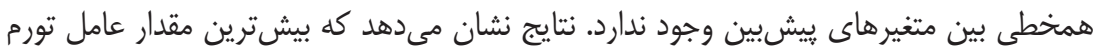

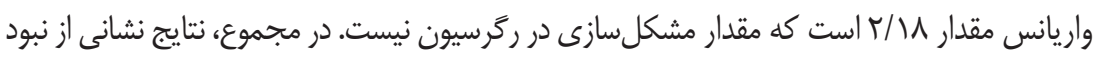
همخطى بين متغير هاى مستقل دارد.

جدول ب: جدول ضرايب آزمون ركر سيون خطى خندكانه با هدف ييشيينى متغير هاى وابسته

\begin{tabular}{|c|c|c|c|c|c|c|c|}
\hline DW & $\mathbf{R}^{2}$ & VIF & Beta & SE & B & متغير مستقل & متغير وابسته \\
\hline \multirow[t]{4}{*}{$T / Y \wedge$} & $\cdot / 01$ & & &.$/ K Y$. &.$- \cdot 10$ & مقدار ثابت & \multirow{2}{*}{$\begin{array}{cc}9 \\
3 \\
3 & 0\end{array}$} \\
\hline & & $1 / \mathrm{VV}$ & $-\cdot / \cdot \wedge r$ & $\cdot / 1 \cdot 4$ & $-.1 .9 \mathrm{~V}$ & ديدكاه راهبردى & \\
\hline & & $r / \Lambda \Lambda$ & $* \cdot \pi \wedge \varphi$ &.$/ I V T$ & $\cdot / 490$ & معمارى سازمانى & \\
\hline & & $r / T Y$ & $* \cdot$ rVq & $\cdot / 1 / 9$ & $\cdot / 4 \cdot 1$ & كرايش و رفتار كارآفرينانه & \\
\hline \multirow[t]{4}{*}{$1 / 91$} & $\cdot / \uparrow \wedge$ & & &.$/ D K Y$ & $-\cdot / 4 r q$ & مقدار ثابت & \multirow{4}{*}{ 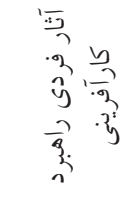 } \\
\hline & & $1 / 94$ & $* * * / \uparrow \vee$ &.$/ 199$ & $\cdot 190 \mathrm{r}$ & ديدكاه راهبردى & \\
\hline & & $1 / V^{4}$ & $\cdot / r Q$. & $\cdot / \mathrm{VA}$ & $\cdot / \mu \cdot \Delta$ & معمارى سازمانى & \\
\hline & & $1 / 19$ & 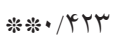 & س س اת/. & $\cdot / K Y D$ & كرايش و رفتار كارآفرينانه & \\
\hline
\end{tabular}

توجه:

1. Durbin Watson

2. VIF 


\section{بحث و نتيجه كيرى}

با توجه به موضوع يزوهش مبنى بر بررسى آثار راهبرد كارآفرينى سازمانى، در ابتدا عناصر

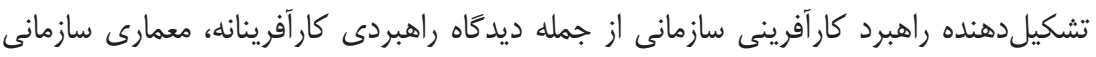

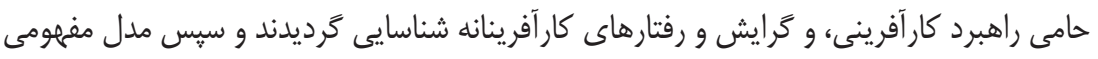
در شركتهاى تحت يوشش سازمان توسعه و نوسازى معادن و صنايع معدنى إئى ايران (ايميدرو) بكار

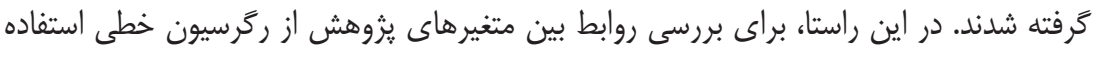

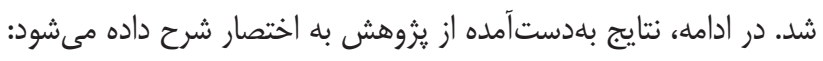

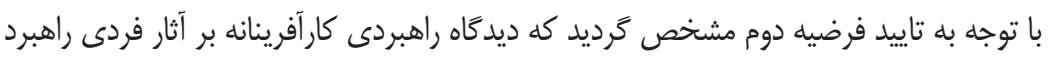

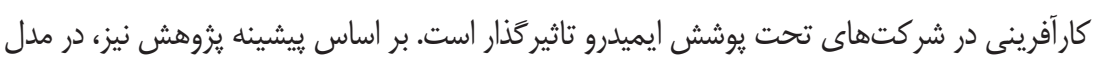

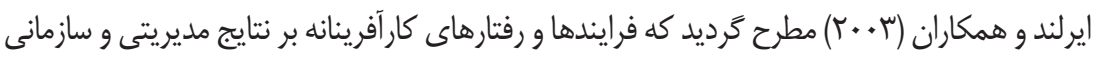

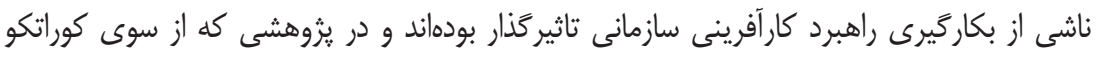

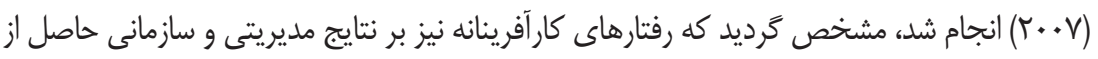

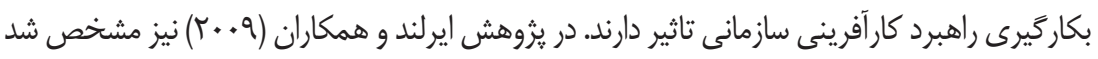

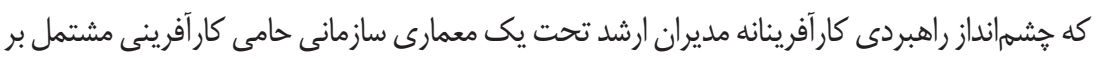

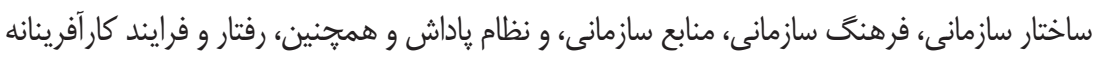

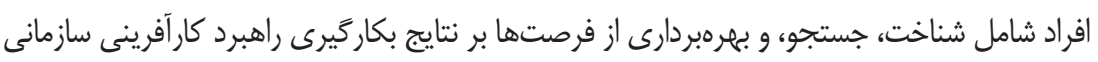

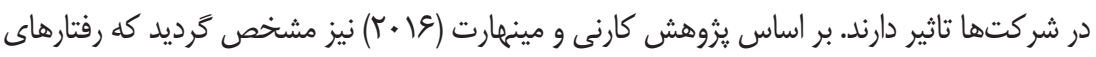

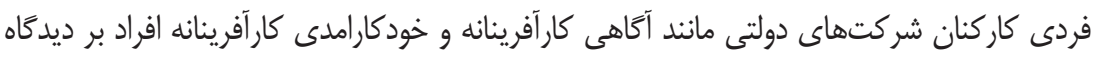

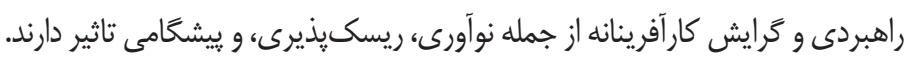

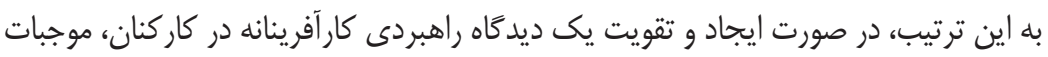

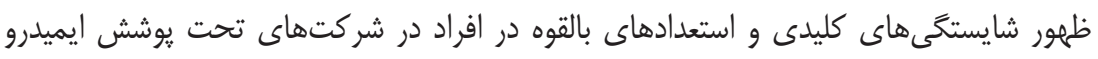

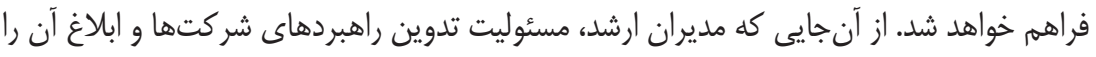

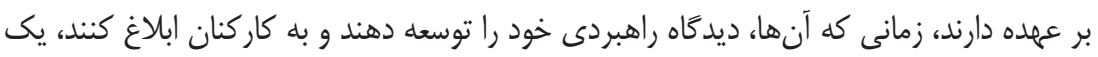

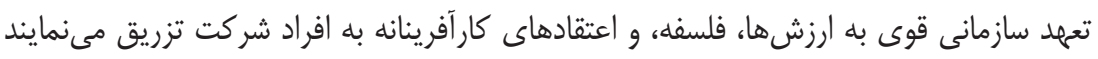

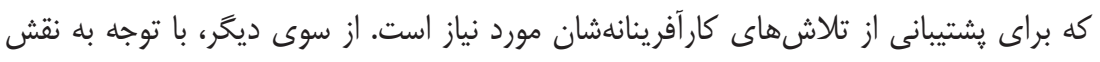

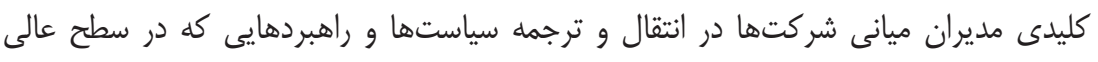

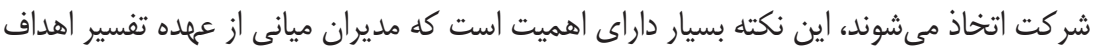


راهبردى مد نظر مديران ارشد بهخوبى برمىآيند و مىتوانند مسائل را در جهت اجرايى شدن به

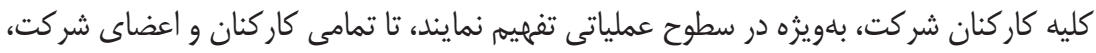

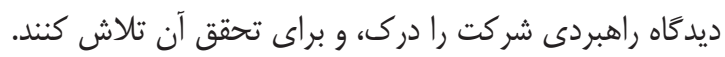

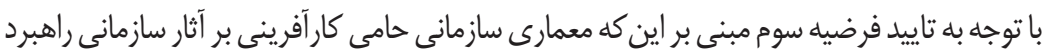

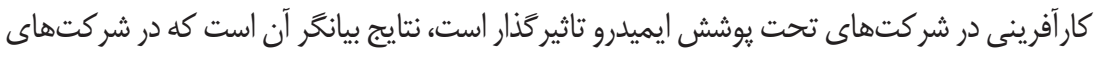

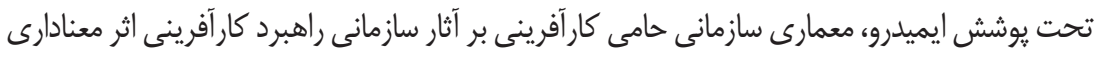

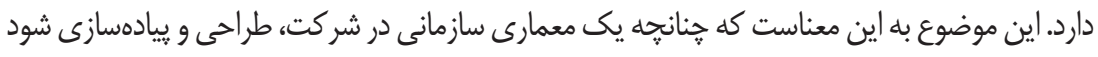

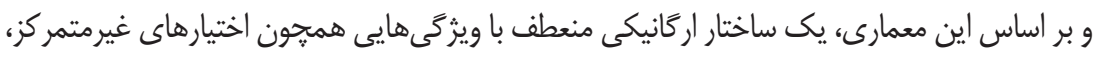

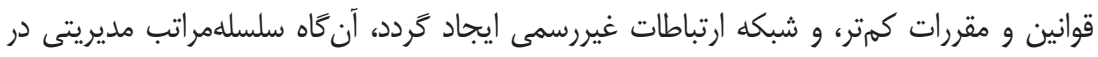

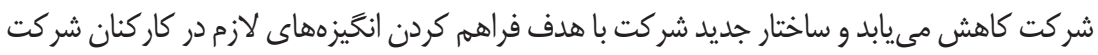

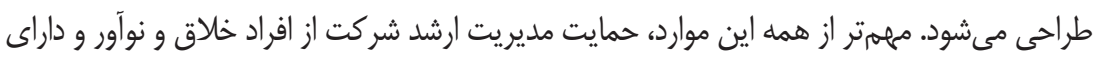

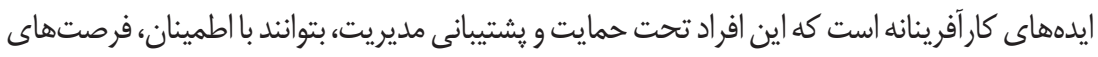

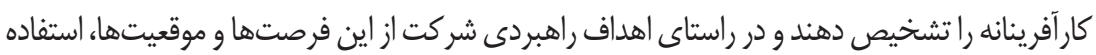

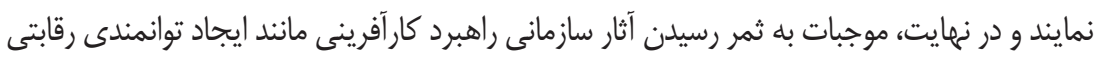

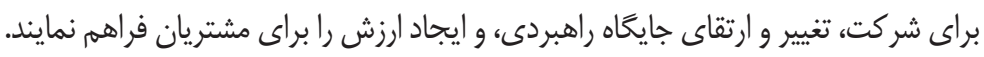

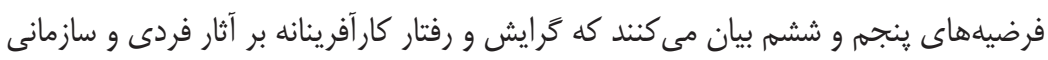

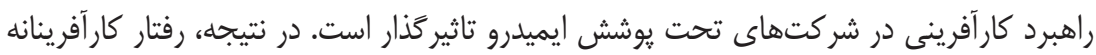

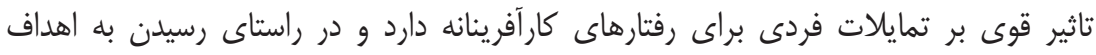

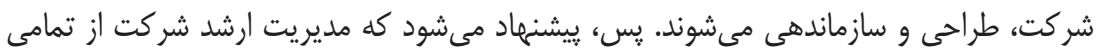

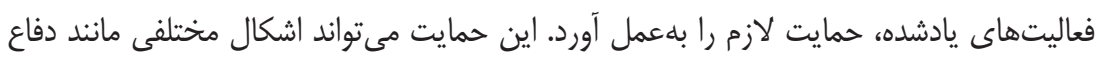

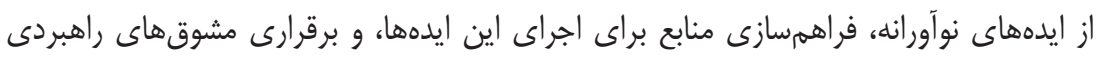

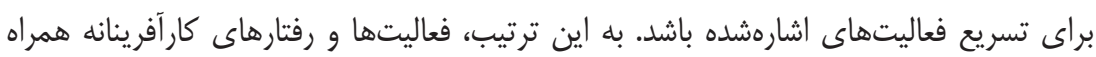

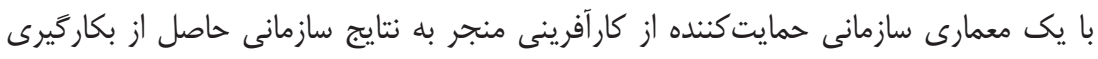

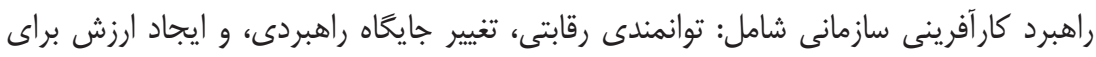

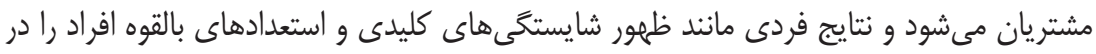
شركتهاى تحت يوشش ايميدرو به دنبال خواهد داشت.

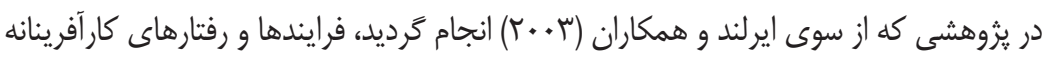

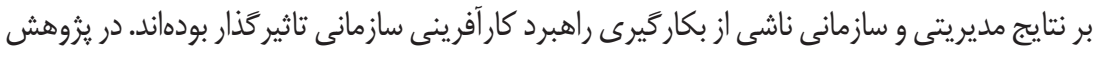




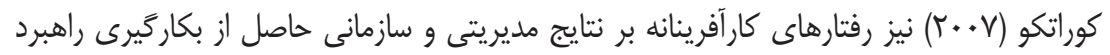

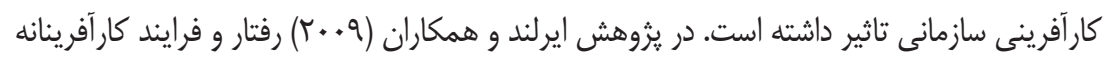

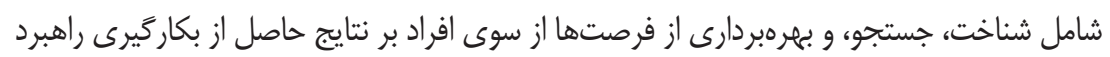

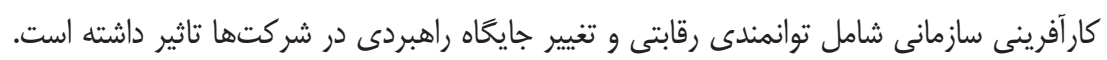

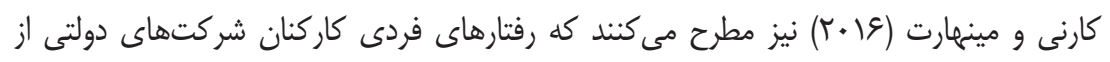

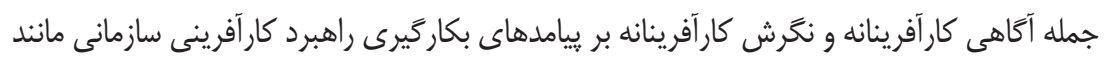

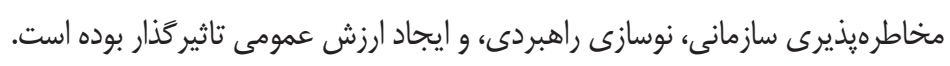

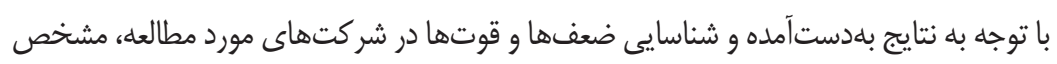

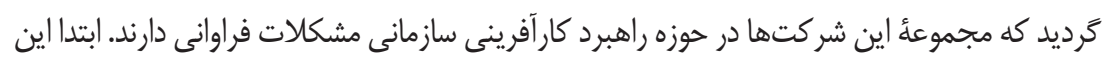

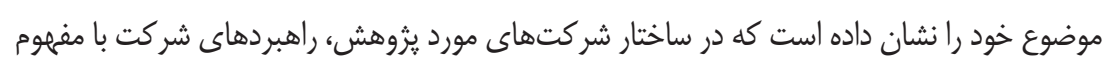

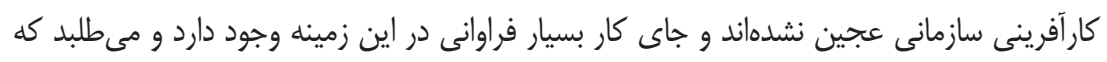

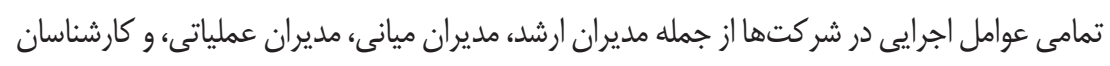

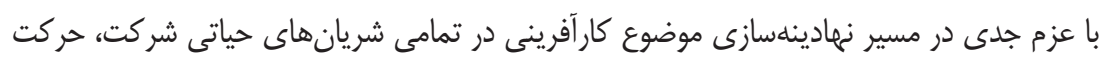

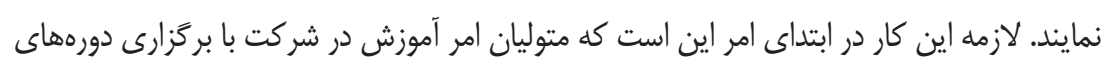

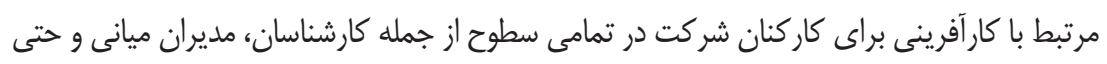

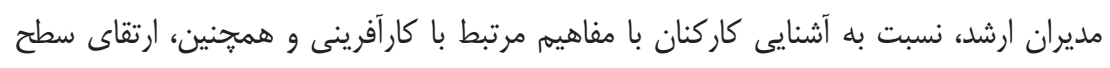

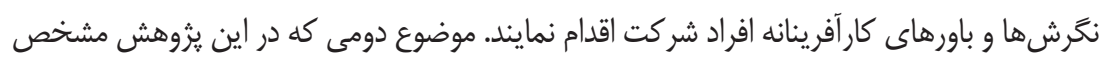

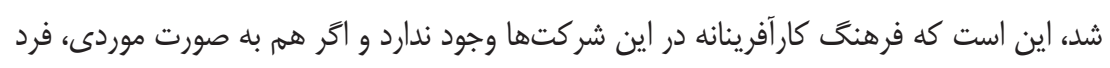

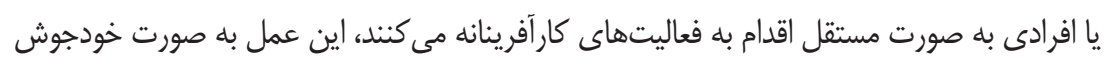

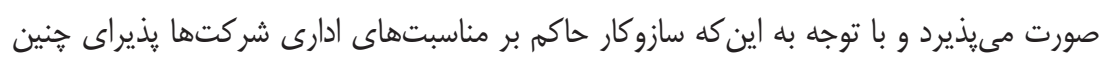

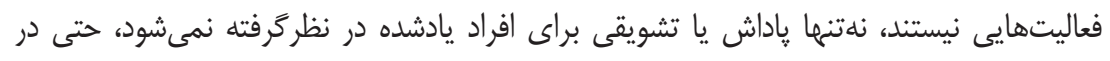

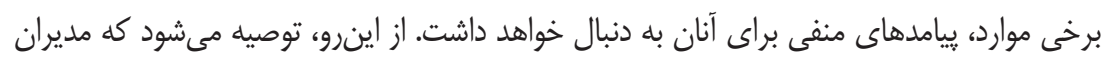

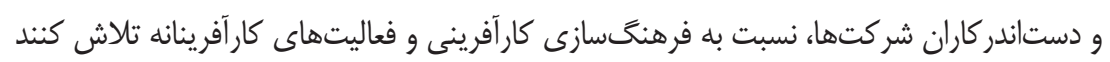

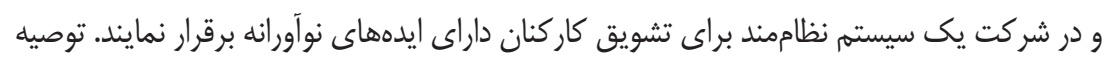

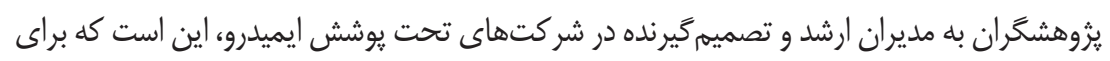

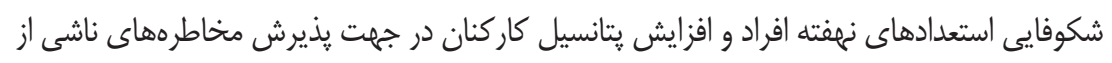

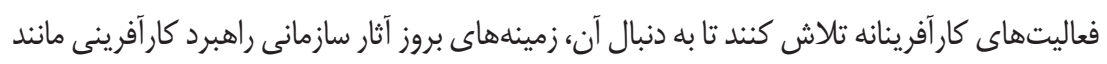
ايجاد توانمندى براى شركت در جهت مقابله با رقبا و ارتقاى جايخاه شركت فراهم كرد درد. 
در پايان، به بُزوهشكَران بيشنهاد مىشود كه آثار راهبرد كارآفرينى سازمانى را در محيطهاى

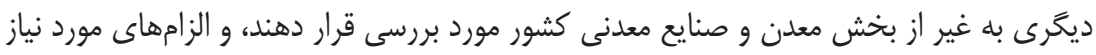

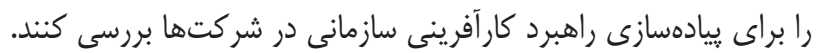

$$
\begin{aligned}
& \text { الف) فارسى }
\end{aligned}
$$

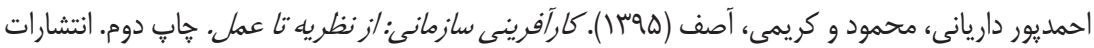

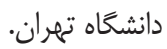

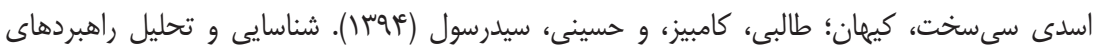

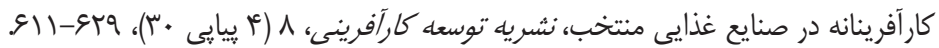

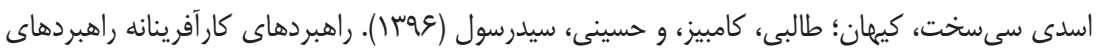

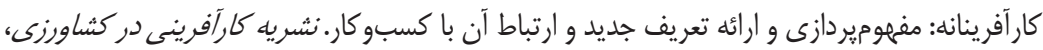
S)-VT، (T)

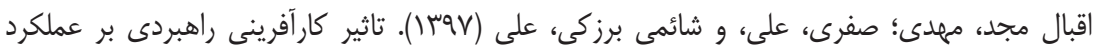

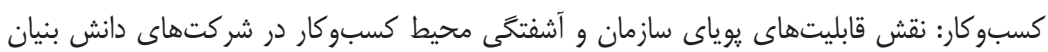

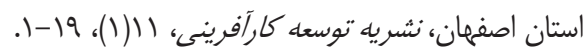

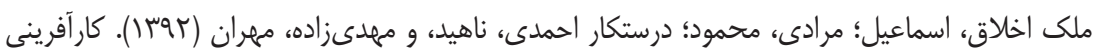

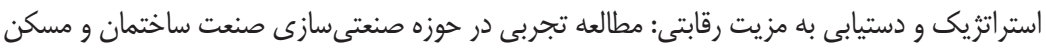

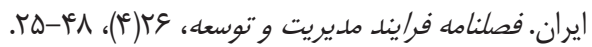

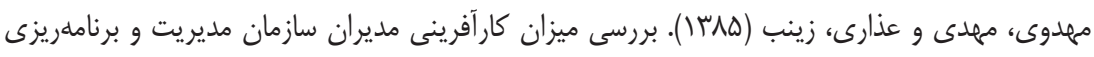

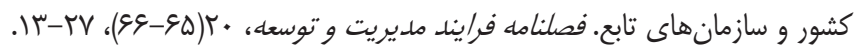

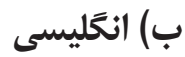

Amit, R. H., Brigham, K., \& Markman, G. D. (2000). Entrepreneurial Management as Strategy. Entrepreneurship as Strategy: Competing on the Entrepreneurial Edge, 83-89.

Barney, J. (1991). Firm Resources and Sustained Competitive Advantage. Journal of Management, 17(1), 99-120.

Bradley, S. W., Wiklund, J., \& Shepherd, D. A. (2011). Swinging A Double-Edged Sword: The Effect of Slack on Entrepreneurial Management and Growth. Journal of Business Venturing, 26(5), 537-554. 
Covin, J. G., \& Miles, M. P. (1999). Corporate Entrepreneurship and the Pursuit of Competitive Advantage. Entrepreneurship Theory and Practice, 23(3), 47-63.

Crawford, G. C., \& Kreiser, P. M. (2015). Corporate Entrepreneurship Strategy: Extending the Integrative Framework through the Lens of Complexity Science. Small Business Economics, 45(2), 403-423.

David, O., \& Ted, G. (1992). Reinventing Government: How the Entrepreneurial Spirit is Transforming the Public Sector: Prentice Hall of India.

Govindarajan, V., \& Trimble, C. (2005). Building Breakthrough Businesses within Established Organizations. Harvard Business Review, 83(5), 58-68, 152.

Guth, W. D., \& Ginsberg, A. (1990). Guest Editors' Introduction: Corporate Entrepreneurship. Strategic Management Journal, 11(1), 5-15.

Hitt, M. A., Ireland, R. D., Sirmon, D. G., \& Trahms, C. A. (2011). Strategic Entrepreneurship: Creating Value for Individuals, Organizations, and Society. Academy of Management Perspectives, 25(2), 57-75.

Hornsby, J. S., Kuratko, D. F., \& Zahra, S. A. (2002). Middle Managers' Perception of the Internal Environment for Corporate Entrepreneurship: Assessing a Measurement Scale. Journal of Business Venturing, 17(3), 253-273.

Ireland, R. D., \& Webb, J. W. (2007). Strategic Entrepreneurship: Creating Competitive Advantage through Streams of Innovation. Business Horizons, 50(1), 49-59.

Ireland, R. D., Covin, J. G., \& Kuratko, D. F. (2009). Conceptualizing Corporate Entrepreneurship Strategy. Entrepreneurship Theory and Practice, 33(1), 19-46.

Ireland, R. D., Kuratko, D. F., \& Covin, J. G. (2003). Antecedents, Elements, and Consequences of Corporate Entrepreneurship Strategy. Paper Presented at the Academy of Management Proceedings.

Kearney, C., \& Meynhardt, T. (2016). Directing Corporate Entrepreneurship Strategy in the Public Sector to Public Value: Antecedents, Components, and Outcomes. International Public Management Journal, 19(4), 543-572.

Kearney, C., Hisrich, R. D., \& Roche, F. (2009). Public and Private Sector Entrepreneurship: Similarities, Differences or a Combination? Journal of Small Business and Enterprise Development, 16(1), 26-46.

Kearney, C., Hisrich, R., \& Roche, F. (2008). A Conceptual Model of Public Sector Corporate Entrepreneurship. International Entrepreneurship and Management Journal, 4(3), 295-313.

Kuratko, D. F. (2007). Corporate Entrepreneurship. Foundations and Trends ${ }^{\circledR}$ in Entrepreneurship, 3(2), 151-203. 
Kuratko, D. F., \& Audretsch, D. B. (2009). Strategic Entrepreneurship: Exploring Different Perspectives of an Emerging Concept. Entrepreneurship Theory and Practice, 33(1), 1-17.

Kuratko, D. F., Hornsby, J. S., \& Covin, J. G. (2014). Diagnosing a Firm's Internal Environment for Corporate Entrepreneurship. Business Horizons, 57(1), 37-47.

Kuratko, D. F., Ireland, R. D., Covin, J. G., \& Hornsby, J. S. (2005). A Model of Middle-Level Managers' Entrepreneurial Behavior. Entrepreneurship Theory and Practice, 29(6), 699-716.

Kuratko, D. F., McMullen, J. S., Hornsby, J. S., \& Jackson, C. (2017). Is Your Organization Conducive to the Continuous Creation of Social Value? Toward a Social Corporate Entrepreneurship Scale. Business Horizons, 60(3), 271-283.

Miller, D. (1983). The Correlates of Entrepreneurship in Three Types of Firms. Management Science, 29(7), 770-791.

Mokaya, S. O. (2012). Corporate Entrepreneurship and Organizational Performance Theoretical Perspectives, Approaches and Outcomes. International Journal of Arts and Commerce, 1(4), 133-143.

Morris, M. H., \& Kuratko, D. F. (2002). Corporate Entrepreneurship: Entrepreneurial Development within Organizations: South-Western Pub.

Morris, M. H., Kuratko, D. F., \& Covin, J. G. (2010). Corporate Entrepreneurship \& Innovation: Cengage Learning.

Peltola, S. (2012). Can an Old Firm Learn New Tricks? A Corporate Entrepreneurship Approach to Organizational Renewal. Business Horizons, 55(1), 43-51.

Sakhdari, K. (2016). Corporate Entrepreneurship: A Review and Future Research Agenda. Technology Innovation Management Review, 6(8), 5-18.

Simsek, Z., Heavey, C., \& Fox, B. C. (2017). (Meta-) Framing Strategic Entrepreneurship. Strategic Organization, 15(4), 504-518.

Warrick, D., Milliman, J. F., \& Ferguson, J. M. (2016). Building High Performance Cultures. Organizational Dynamics, 1(45), 64-70.

Wolcott, R. C., \& Lippitz, M. J. (2007). The Four Models of Corporate Entrepreneurship. MIT Sloan Management Review, 49(1), 75-82.

Zahra, S. A. (1996). Governance, Ownership, and Corporate Entrepreneurship: The Moderating Impact of Industry Technological Opportunities. Academy of Management Journal, 39(6), 1713-1735.

Zahra, S. A., Ireland, R. D., Gutierrez, I., \& Hitt, M. A. (2000). Introduction to Special Topic Forum Privatization and Entrepreneurial Transformation: Emerging Issues and a Future Research Agenda. Academy of Management Review, 25(3), 509-524. 